\section{OPEN ACCESS}

Edited by:

Aurélien Paulmier,

UMR5566 Laboratoire d'études en géophysique et océanographie spatiales (LEGOS), France

Reviewed by: Jacqueline L. Padilla-Gamino, University of Washington, United States Laura Ramajo,

Adolfo Ibáñez University, Chile

*Correspondence: Kirk N. Sato kirk.sato@oist.jp

Specialty section:

This article was submitted to Global Change and the Future Ocean,

a section of the journal

Frontiers in Marine Science

Received: 16 April 2018

Accepted: 11 July 2018

Published: 22 August 2018

Citation:

Sato KN, Andersson AJ, Day JMD,

Taylor JRA, Frank MB, Jung J-Y,

McKittrick J and Levin LA (2018)

Response of Sea Urchin Fitness Traits to Environmental Gradients Across the Southern California Oxygen Minimum

Zone. Front. Mar. Sci. 5:258. doi: 10.3389/fmars.2018.00258

\title{
Response of Sea Urchin Fitness Traits to Environmental Gradients Across the Southern California Oxygen Minimum Zone
}

Kirk N. Sato ${ }^{1 *}$, Andreas J. Andersson ${ }^{1}$, James M. D. Day ${ }^{1}$, Jennifer R. A. Taylor ${ }^{1}$, Michael B. Frank ${ }^{2}$, Jae-Young Jung ${ }^{2}$, Joanna McKittrick ${ }^{2,3}$ and Lisa A. Levin ${ }^{1}$
${ }^{1}$ Scripps Institution of Oceanography, University of California, San Diego, La Jolla, CA, United States, ${ }^{2}$ Materials Science and Engineering Program, University of California, San Diego, La Jolla, CA, United States, ${ }^{3}$ Department of Mechanical and Aerospace Engineering, University of California, San Diego, La Jolla, CA, United States

Marine calcifiers are considered to be among the most vulnerable taxa to climate-forced environmental changes occurring on continental margins with effects hypothesized to occur on microstructural, biomechanical, and geochemical properties of carbonate structures. Natural gradients in temperature, salinity, oxygen, and $\mathrm{pH}$ on an upwelling margin combined with the broad depth distribution (100-1,100 m) of the pink fragile sea urchin, Strongylocentrotus (formerly Allocentrotus) fragilis, along the southern California shelf and slope provide an ideal system to evaluate potential effects of multiple climate variables on carbonate structures in situ. We measured, for the first time, trait variability across four distinct depth zones using natural gradients as analogues for species-specific implications of oxygen minimum zone (OMZ) expansion, deoxygenation and ocean acidification. Although $S$. fragilis may likely be tolerant of future oxygen and $\mathrm{pH}$ decreases predicted during the twenty-first century, we determine from adults collected across multiple depth zones that urchin size and potential reproductive fitness (gonad index) are drastically reduced in the OMZ core (450-900 m) compared to adjacent zones. Increases in porosity and mean pore size coupled with decreases in mechanical nanohardness and stiffness of the calcitic endoskeleton in individuals collected from lower $\mathrm{pH}_{\text {Total }}(7.57-7.59)$ and lower dissolved oxygen (13-42 $\mu \mathrm{mol} \mathrm{kg}{ }^{-1}$ ) environments suggest that $S$. fragilis may be potentially vulnerable to crushing predators if these conditions become more widespread in the future. In addition, elemental composition indicates that $S$. fragilis has a skeleton composed of the low Mg-calcite mineral phase of calcium carbonate ( mean $\mathrm{Mg} / \mathrm{Ca}=0.02 \mathrm{~mol} \mathrm{~mol}^{-1}$ ), with $\mathrm{Mg} / \mathrm{Ca}$ values measured in the lower end of values reported for sea urchins known to date. Together these findings suggest that ongoing declines in oxygen and $\mathrm{pH}$ will likely affect the ecology and fitness of a dominant echinoid on the California margin.

Keywords: ocean deoxygenation, ocean acidification, echinoid, sea urchin, Strongylocentrotus fragilis, oxygen minimum zone, carbonate geochemistry, biomechanics 


\section{INTRODUCTION}

Continental margin ecosystems along eastern boundary upwelling systems experience sharp natural gradients in temperature, salinity, dissolved oxygen (DO), and $\mathrm{pH}$ over short vertical distances (Feely et al., 2008; Levin and Sibuet, 2012; Sperling et al., 2016; Figure 1). In the eastern Pacific these gradients are associated with oxygen minimum zones (OMZs) that originate from combined respiration of abundant sinking organic matter and reduced exposure to more oxygenated water masses (Gilly et al., 2013). In contrast to regions affected by coastal hypoxia, which are primarily caused by eutrophication (Diaz and Rosenberg, 2008), OMZs are formed via natural processes (Helly and Levin, 2004; Breitburg et al., 2018). In the Southern California Bight (SCB) OMZ, two distinct intermediate water masses converge and contribute to upwelled source water: the relatively cool, less saline, high-DO, high $\mathrm{pH}$ Pacific Subarctic Upper Water (PSUW) advected from the north and the relatively warm, salty, low-DO, low-pH Pacific Equatorial Water (PEW) advected from the south (Nam et al., 2015). OMZs are defined as midwater areas where DO levels are $<22 \mu \mathrm{mol} \mathrm{kg}{ }^{-1}(<0.5 \mathrm{ml}$ $1^{-1}$ ), and OMZ properties (e.g., thickness, boundary depths, seasonality, oxygen minima values) vary geographically (Helly and Levin, 2004; Gallo and Levin, 2016) and over multiple time-scales (Moffitt et al., 2015). In recent decades, OMZs have appeared to expand in tropical and subtropical regions (Stramma et al., 2010; Schmidtko et al., 2017; Levin, 2018) with major ecological implications for marine populations and communities (Gilly et al., 2013; Gallo and Levin, 2016; Sato et al., 2017).

According to life-history theory, the variability of key life-history traits for organisms, including body size, gonad index, and properties of structural elements confer species variable fitness (Lack, 1947; Smith and Fretwell, 1974; Denny et al., 1985; Fabian and Flatt, 2012; MacLean and Beissinger, 2017). Continental margin communities and species that are exposed to concomitant drivers associated with anthropogenic climate change such as warming, ocean acidification (OA) and deoxygenation are excellent candidates to investigate trait variability patterns (Gruber, 2011; Kroeker et al., 2016). To better understand the evolutionary and ecological consequences of multiple climate change drivers in the ocean such as OA and deoxygenation, it is critical to characterize environmental effects on the variability of traits linked to fitness in situ within key species (i.e., phenotypic buffering) (Reusch, 2014; Sunday et al., 2014; Swezey et al., 2017a; Des Roches et al., 2018). The upper and lower boundaries of severe OMZs on upwelling margins exhibit strong vertical zonation of benthic invertebrate communities, with rapid shifts from dense benthic megafauna and calcareous invertebrates outside the OMZ to communities dominated by annelids and calcareous foraminifera within the OMZ (Levin, 2003; Gooday et al., 2010). Only recently has there been investigation of the interplay of temperature, oxygen and $\mathrm{pH}$ effects on extant benthos in these areas (Sperling et al., 2016; Sato et al., 2018).
Echinoid sea urchins are important benthic grazers (Pearse, 2006), algal detritivores (Barry et al., 2014; Sato et al., 2018) and deposit feeders (Lohrer et al., 2005). The pink urchin, Strongylocentrotus fragilis, is a dominant megafaunal species on the outer shelf $(120-200 \mathrm{~m})$ and upper slope $(200-500 \mathrm{~m})$ in southern California (Thompson et al., 1993; Sato et al., 2017; Walther et al., 2017). S. fragilis also occurs, although infrequently, in the OMZ core (500-900 m) and below the OMZ core, in the Lower OMZ (LOMZ; 900-1,200 m) where DO and $\mathrm{pH}$ are higher than in the OMZ core (Sumich and McCauley, 1973; Barry et al., 2014; Taylor et al., 2014; Figure 1). Sato et al. (2018) previously described natural history traits of $S$. fragilis in the SCB including spatial variability in density, distribution, feeding behavior, and relative growth rates, as well as seasonal patterns in reproductive potential. S. fragilis thus serves as a model species to evaluate how multiple parameters that are likely to be modified under climate change (e.g., temperature, $\mathrm{DO}$, and $\mathrm{pH}$ ) may potentially influence sublethal fitness traits on both macro- and microscale levels (Byrne et al., 2014; Taylor et al., 2014; Carrington et al., 2015; Swezey et al., 2017b).

There is compelling evidence that projected future changes in ocean temperature, carbonate chemistry, and DO will affect morphological function of calcified hard parts and fitness success. For example, weaker structures in intertidal mussels (Gaylord et al., 2011; Carrington et al., 2015), crustaceans (Taylor et al., 2015; deVries et al., 2016; Lowder et al., 2017), coccolithophorids (Ziveri et al., 2014), and sea urchins (Presser et al., 2010; Collard et al., 2016) could increase vulnerability to predation. Sea urchins produce ellipsoid-shaped, calcitic skeletal structures called tests, as well as calcitic spines, both of which provide the organism with a variety of critical functions such as protection against predators, sensing, locomotion, and feeding (Pearse, 2006). An improved understanding of the relationship between material properties (e.g., hardness, stiffness) of $S$. fragilis skeletal tests and the environmental gradients they experience on the continental margin can provide valuable information regarding $S$. fragilis potential survival under climate change and its vulnerability to crushing predators (e.g., crabs and fish).

Calcified sea urchin tests are typically composed primarily of calcite $\left(\mathrm{CaCO}_{3}\right)$ with various amounts of magnesium incorporated in their calcareous structures (i.e., $\mathrm{MgCO}_{3}$ or $\mathrm{Mg}$ calcite). Organisms that produce $\mathrm{Mg}$ calcite containing significant amounts of $\mathrm{Mg}$ are potentially highly vulnerable to future changes in the seawater carbonate system linked to anthropogenic increases in atmospheric $\mathrm{pCO}_{2}$ as $\mathrm{Mg}$ calcite phases with $8-12 \mathrm{~mol} \% \mathrm{MgCO}_{3}$ are more soluble than aragonite (Walter and Morse, 1984; Morse et al., 2006; Andersson et al., 2008). While several datasets quantify $\% \mathrm{MgCO}_{3}$ in fieldcollected sea urchins (e.g., Clarke and Wheeler, 1917; Chave, 1954; Kuklinski and Taylor, 2009) and in controlled laboratory experiments (e.g., Hermans et al., 2010; Lavigne et al., 2013), the biomineral $\mathrm{Mg}$ composition of $S$. fragilis, a potential climate change-tolerant species, has yet to be reported. In addition, few studies attempt to link spatial patterns of $\mathrm{Mg}$ content with material properties of calcified hard parts in the context of physicochemical variables affected by climate change (Byrne et al., 2014). Notably, some deep-water echinoderms distributed 


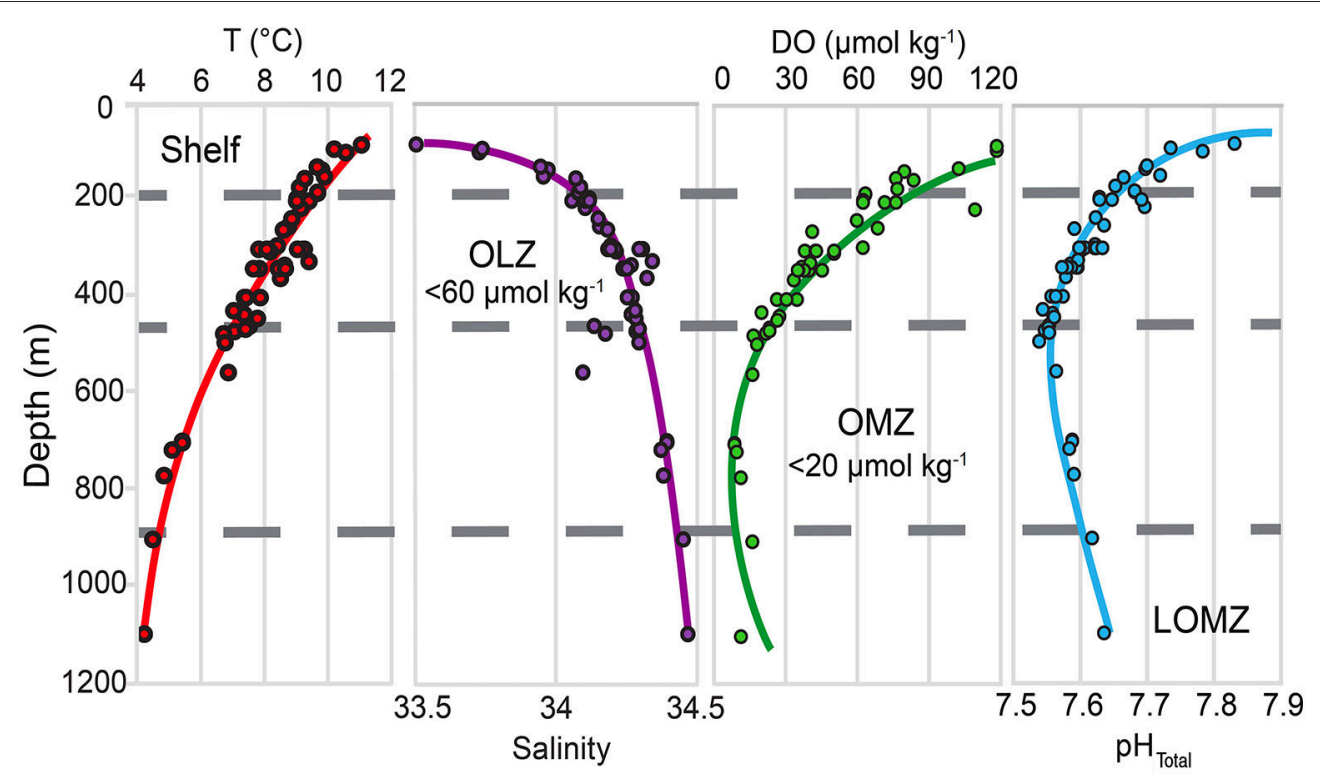

FIGURE 1 | Depth profiles for temperature (T), salinity, dissolved oxygen (DO), and in situ $\mathrm{pH}_{\text {Total }}$ in southern California, indicating the vertical structure of key variables likely to be modified under climate change. Horizontal gray dashed lines separate the continental margin into four depth zones: Shelf, Oxygen Limited Zone (OLZ), Oxygen Minimum Zone (OMZ), and Lower Oxygen Minimum Zone (LOMZ). Points indicate trawl depths of urchin collection sites throughout southern California.

across the globe have been found to be tolerant of waters undersaturated with respect to the polymorph of their speciesspecific calcareous structure $\left(\Omega_{\mathrm{i}}<1\right)$ (Lebrato et al., 2016).

In some biogenic structures, metal enrichment can form significantly tougher composite structures (Naleway et al., 2016). For example, the protodolomite stone part of each tooth of the urchin feeding apparatus (Aristotle's lantern) can exceed 40$45 \% \mathrm{MgCO}_{3}$ (Wang et al., 1997), which may have led to the taxon's evolutionary success (Candia Carnevali et al., 1993; Ma et al., 2009; Reich and Smith, 2009; Frank et al., 2015). Further evidence suggests that temperature, but not $\mathrm{pH}$, may be positively related to both $\mathrm{Mg}$ content and hardness of some urchin's calcitic structures (Byrne et al., 2014), while another study suggested $\mathrm{Mg}$ was not related to hardness (Moureaux et al., 2010). In addition to $\mathrm{Mg}$, numerous other co-precipitated elements are differentially incorporated into biotic calcitic structures such as phosphorus (P; e.g., calcium phosphate) and strontium (Sr; e.g., strontium calcite) (Mackenzie et al., 1983). Some trace metals, such as iron (Fe) and zinc $(\mathrm{Zn})$, have been found to enhance mechanical properties of biomineralized structures (e.g., iron oxides, zinc oxides), and inspire the development of anthropogenic biomaterials (Meyers et al., 2008; Agaogullari et al., 2012; Naleway et al., 2016).

To better understand the link between environmental change and fitness, we set out to elucidate the relationships among physicochemical variables (temperature, salinity, DO, and $\mathrm{pH}$ ) and skeletal traits (morphological, biomineral element composition, material properties and microstructure) of $S$. fragilis across the southern California OMZ. Our main objective was to measure variability of $S$. fragilis across four depth zones (Shelf, OLZ, OMZ, and Lower OMZ) with associated differences in temperature, salinity, DO, and $\mathrm{pH}$.
We compared the following five potential fitness traits: (i) size (test diameter), (ii) gonad index, (iii) biomineral element composition, (iv) material properties (hardness and stiffness), and (v) test microstructure (porosity). We hypothesized that $S$. fragilis in the Shelf zone would exhibit the highest mean size and gonad index, strongest skeletal tests, and lowest porosity compared to conspecifics in OLZ, OMZ, and LOMZ depth bins because the unfavorable environmental conditions in these zones (lower $\mathrm{T}, \mathrm{O}_{2}, \mathrm{pH}$, and food availability) should limit calcification, growth, and gonadal production.

\section{MATERIALS AND METHODS}

\section{Field Sampling}

To better understand the relationships of urchin body size, reproductive potential, and various biogeochemical, biomechanical, and material properties across multiple environmental gradients, Strongylocentrotus fragilis individuals were collected from various depths between 77 and $1,116 \mathrm{~m}$ throughout the SCB using depth-stratified otter trawls over a period of four years between July 2012 and July 2016 (see Sato et al., 2017). Urchins were collected year-round in collaboration with the Southern California Coastal Water Research Project's Bight'13 Trawl Survey (2013), the National Oceanic and Atmospheric Administration (NOAA) West Coast Groundfish Bottom Trawl Survey (2014), as well as Scripps Institution of Oceanography (SIO) course cruises and SIO student cruises in 2014-2016 on the R/V Robert Gordon Sproul, the R/V New Horizon, and the R/V Melville. During each trawl, the GPS coordinates and bottom depth of the trawl start location were recorded (Supplementary Material, Table S1). Upon retrieval, $\sim 25$ S. fragilis urchins were haphazardly selected, frozen at 
$-20^{\circ} \mathrm{C}$ on board and transported back to the laboratory at SIO where they were maintained in $\mathrm{a}-20^{\circ} \mathrm{C}$ freezer until analysis.

For elemental, biomechanical, and porosity analyses, a subset of urchins were selected from the following four depth zones, corresponding to the concomitant environmental variables (Figure 1 and Table 1): continental shelf (Shelf; 80-200 m), oxygen limited zone (OLZ; 201-450 m), oxygen minimum zone (OMZ; 451-900 m), and lower oxygen minimum zone (LOMZ; 901-1,116 m).

\section{Hydrographic Data}

Each SCB trawl was assigned a single value for temperature, salinity, $\mathrm{DO}$, and $\mathrm{pH}$ near $(<10 \mathrm{~m}$ from seafloor) or on the seafloor (Figure 1). Hydrographic data were obtained in one of three ways: (1) During the 2014 NOAA survey cruise, conductivity, temperature, depth, and dissolved oxygen sensors $\left(\mathrm{CTD}-\mathrm{O}_{2}\right)$ (Sea-Bird Scientific, Bellevue, WA, USA, SBE 19plus) were directly attached to the trawl net. These recorded in situ temperature $\left({ }^{\circ} \mathrm{C}\right)$, salinity (PSU), and DO $\left(\mu \mathrm{mol} \mathrm{kg}{ }^{-1}\right)$. (2) During the SIO cruises, CTD- $\mathrm{O}_{2}$ casts (Sea-Bird Scientific, Bellevue, WA, USA) were conducted immediately before the trawls were deployed. (3) Historical CTD-O $\mathrm{O}_{2}$ data from quarterly hydrographic cruises conducted by the California Cooperative Oceanic Fisheries Investigations (CalCOFI) were obtained from the CalCOFI station, sampling date and depth nearest in space and time to the trawl providing urchins. Although direct comparison of hydrographic data across methods was not possible because data were collected at different locations and times, each instrument was pre-calibrated according to manufacturer specifications or by applying a linear correction based on discrete samples (Nam et al., 2015).

Data for $\mathrm{pH}_{\text {Total }}$ were obtained in two ways: (1) In San Diego, discrete water samples were taken at depths by CTD rosette corresponding to urchin trawls aboard the R/V Melville during the student-led San Diego Coastal Expedition cruises in June/July and December 2012. Briefly, water samples were collected in Pyrex serum bottles following standard procedures (Dickson et al., 2007). Within $4 \mathrm{~h}$ of collection, $\mathrm{pH}$ was analyzed spectrophotometrically onboard at $20^{\circ} \mathrm{C}$ using unpurified $\mathrm{m}$ cresol purple as indicator dye. The $\mathrm{pH}$ data accuracy and precision were \pm 0.02 ( 1 s.d.) and \pm 0.0015 , respectively, when compared to certified reference materials (Takeshita et al., 2015). For further discussion, see Nam et al. (2015) and Takeshita et al. (2015). (2) For urchin collection sites in Santa Barbara (<500 m),
$\mathrm{pH}_{\text {Seawater }}$ was calculated using a robust empirical relationship with temperature and dissolved oxygen concentration $\left(r^{2}=0.98\right.$, root mean square error $=0.024$ ) determined by Alin et al. (2012). $\mathrm{pH}_{\text {Seawater }}$ values were converted to the $\mathrm{pH}_{\text {Total }}$ scale using the "pHconv" function in the $\mathrm{R}$ package seacarb. All $\mathrm{pH}_{\text {Total }}$ values were corrected to reflect in situ conditions using the "pHinsi" function with dissociation constants from Lueker et al. (2000) and Dickson (1990).

Data in the upper $500 \mathrm{~m}$ are comparable to mean results of Nam et al. (2015), which described the seasonal variability of multiple underreported hydrographic variables at a relatively high spatial sampling resolution. Our results below $500 \mathrm{~m}$ to basin depths $(>1,000 \mathrm{~m})$, are also consistent with a persistent, well defined OMZ documented in previous published datasets (Nam et al., 2015).

\section{Laboratory Analyses \\ Urchin Size and Gonad Index}

Urchin size and reproductive potential were compared across depth zones to assess relative habitat quality. Frozen urchins were thawed and rinsed clean in the laboratory prior to dissection. Spines were removed prior to measurement of the individual urchin test length diameter (TLD) via calibrated dial calipers to the nearest $0.1 \mathrm{~mm}$. Wet weights of gonads (five lobes) were measured along with the weight of each individual drained of its internal fluids to the nearest 0.001 gram. Gonad Index was calculated as the ratio of gonad wet weight to body weight.

\section{Biomineral Element Composition of Tests}

Multiple elements were measured in the calcified material to better understand the relationships among environmental conditions and mechanical and structural properties. Up to 10 interambulacral ossicle plates from each urchin, located 3-4 ossicles from the apex (dorsal surface), were dissected and airdried in glass vials. Ossicles were transferred to a trace element clean room and placed in $5 \mathrm{~mL}$ plastic vials that had been prewashed with $10 \%$ nitric acid. The ossicles were then soaked in a clean solution of $15 \%$ Optima grade hydrogen peroxide (Fisher Chemical) buffered with $0.05 \mathrm{M}$ Suprapur sodium hydroxide (EMD Chemicals) for approximately $24 \mathrm{~h}$ to remove organic tissue, rinsed in ultrapure water three times, and set to dry under a Class-100 laminar flow hood for approximately $48 \mathrm{~h}$. A total of one to five ossicles from each individual were weighed together (4-15 $\mathrm{mg}$ total weight) and placed in pre-cleaned Teflon vials

TABLE 1 | Mean values ( \pm 1 SE) of hydrographic variables (Depth, Temperature, Salinity, Oxygen, and in situ pH Total), gonad index (\% weight) and total length of the test diameter of urchins separated by depth zone bin.

\begin{tabular}{|c|c|c|c|c|c|c|c|c|}
\hline Zone & $\mathbf{n}$ & Depth (m) & Temp $\left({ }^{\circ} \mathrm{C}\right)$ & Salinity & Oxygen ( $\left.\mu \mathrm{mol} \mathrm{kg}{ }^{-1}\right)$ & $\mathrm{pH}_{\text {Total }}$ & TLD (mm) & Gonad Index \\
\hline Shelf & 134 & $155.36 \pm 3.43$ & $9.64 \pm 0.05$ & $33.98 \pm 0.01$ & $85.05 \pm 1.93$ & $7.69 \pm 0.01$ & $60.46 \pm 1.17$ & $6.57 \pm 0.38$ \\
\hline OLZ & 403 & $328.30 \pm 2.33$ & $8.43 \pm 0.03$ & $34.25 \pm 0.01$ & $41.88 \pm 0.60$ & $7.59 \pm 0.01$ & $48.26 \pm 0.40$ & $4.79 \pm 0.19$ \\
\hline OMZ & 95 & $590.20 \pm 13.33$ & $6.22 \pm 0.11$ & $34.29 \pm 0.01$ & $15.83 \pm 0.56$ & $7.57 \pm 0.01$ & $45.49 \pm 0.82$ & $1.85 \pm 0.18$ \\
\hline LOMZ & 24 & $1014.33 \pm 20.15$ & $4.33 \pm 0.03$ & $34.46 \pm 0.01$ & $13.32 \pm 0.49$ & $7.63 \pm 0.01$ & $51.08 \pm 2.88$ & $4.15 \pm 1.01$ \\
\hline
\end{tabular}

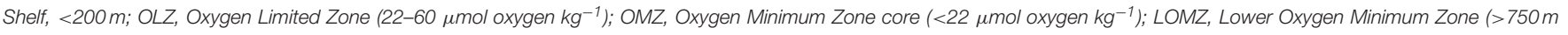
where dissolved oxygen begins to increase). 
for digestion with $1 \mathrm{ml}$ of concentrated Teflon-distilled (TD) nitric acid $\left(14.7 \mathrm{M} \mathrm{HNO}_{3}\right)$ on a hotplate at $100^{\circ} \mathrm{C}$ for $>24 \mathrm{~h}$. Digested samples were dried down, re-acidified with $0.5 \mathrm{~mL}$ TD $\mathrm{HNO}_{3}$, doped with a $1 \mathrm{ppm}$ indium solution (to monitor instrumental drift), and diluted with $3 \mathrm{~mL}$ of ultrapure water to achieve a dilution factor of $250 \times$. Samples were further diluted to achieve a final dilution factor of $8,000 \times$ prior to solution-based analysis using a ThermoScientific $i C A P q$ inductively coupled plasma-mass spectrometer (ICP-MS; Thermo Fisher Scientific $\mathrm{GmbH}$, Bremen, Germany), mass calibrated on the day of analysis. Atomic masses of the elements of interest $\left({ }^{10} \mathrm{~B},{ }^{11} \mathrm{~B}\right.$, ${ }^{25} \mathrm{Mg},{ }^{26} \mathrm{Mg},{ }^{31} \mathrm{P},{ }^{42} \mathrm{Ca},{ }^{44} \mathrm{Ca},{ }^{55} \mathrm{Mn},{ }^{57} \mathrm{Fe},{ }^{60} \mathrm{Ni},{ }^{66} \mathrm{Zn},{ }^{68} \mathrm{Zn},{ }^{86} \mathrm{Sr}$, ${ }^{87} \mathrm{Sr},{ }^{110} \mathrm{Cd},{ }^{111} \mathrm{Cd},{ }^{137} \mathrm{Ba},{ }^{238} \mathrm{U}$ ) were measured for 30 ratios, resulting in internal precision of better than $2 \%$ (2 s.d.). Elements were corrected for total mole fraction. Total procedural blanks run with samples represented $<3 \%$ of the measurement for all elements. Raw data were corrected off line for instrument background, drift and blank. Samples were bracketed by internal standards of Cancer productus crab carapace $(n=4)$, which allowed for calculation of absolute values, although we report ratios relative to $\mathrm{mol} \mathrm{Ca}^{-1}$. The crab standards yielded external precision of better than $2 \%$ for each element, including $\mathrm{Ca}$ ( 2 s.d.) and were calibrated relative to solution and powder standards by bracketing and standard addition procedures. The elements B, P, $\mathrm{Ba}$, and $\mathrm{Mn}$ were not included in the NMDS analysis if data were flagged with greater than $2 \%$ internal precision.

Seawater Element/Ca ratios ( $\mathrm{E}_{\mathrm{SW}} / \mathrm{Casw}$ ) from published datasets collected from sites in the California Current (Biller and Bruland, 2013) and the north Pacific Ocean (Supplementary Material, Figure S1) were used to compare with ICP-MS results. Due to low sample sizes of urchins in LOMZ, these urchins were grouped with OMZ urchins (Table 2). Partition coefficients for each element $\left(D_{E}\right)$ in urchin tests were calculated using the equation,

$$
\mathrm{D}_{\mathrm{E}}=\left(\mathrm{E}_{\mathrm{urchin}} / \mathrm{Ca}_{\mathrm{urchin}}\right) /\left(\mathrm{E}_{\mathrm{Sw}} / \mathrm{Ca} \mathrm{Sw}\right),
$$

where $\mathrm{E}$ represented the element concentration and $\mathrm{Ca}$ was the calcium concentration (in the urchin ossicles as measured by ICP-MS and in seawater as estimated from published datasets).

\section{Test Biomechanical Properties}

To evaluate potential susceptibility to predation by crushing across depth zones, hardness (i.e., resistance to permanent indentation) and stiffness (i.e., elastic modulus, or resistance to elastic deformation) of each ossicle were measured using a nanoindentation materials testing machine (Nano Hardness Tester, Nanovea, Irvine, CA, USA) equipped with a $200-\mu \mathrm{m}$ diameter spherical tip. Ossicle surfaces were smoothed using ultra fine sandpaper (P6000) and then rinsed with MilliQ water and dried under a hood. Sanded ossicles were mounted with super glue onto a steel block (Supplementary Material, Figure S2). Indentations were performed by penetrating into each ossicle with a maximum load of $30 \mathrm{mN}$ and loading and unloading rates of $60 \mathrm{mN} \mathrm{min}{ }^{-1}$. A total of three to five indents were made on each ossicle (1-2 ossicles from each individual, $n=8-15$ indiv. depth $z^{-2} e^{-1}$ ). All indents were spaced sufficiently apart (a minimum of 10 times the penetration depth) to avoid influence from adjacent indents.

\section{Test Porosity}

To better understand the structural implications of variable environmental conditions and drivers of biomechanical properties, test porosity was also determined across depth zones. Replicate ossicles (also located 3-4 interambulacral plates away from the apex) were bisected using a razor blade, carefully cleaned using a paintbrush under a stereomicroscope, secured to a double $90^{\circ}$ SEM mount revealing the cross-section (Supplementary Material, Figure S3), and sputter coated with iridium (Emitech sputter coater K575X) for image analysis using scanning electron microscopy (SEM). Images of urchin plate cross-sections (three per plate) were obtained at 300$400 \times$ magnification using an ultra-high-resolution SEM (FEI XL-30 SFEG Scanning Electron Microscope) set to an acceleration voltage of $5 \mathrm{kV}$ to achieve a resolution of $2.5 \mathrm{~nm}$. SEM micrographs were analyzed for porosity (\%) by calculating the ratio of pore area to total area of the micrograph using ImageJ (Supplementary Material, Figure S3; Schneider et al., 2012). The color threshold for each 2-D SEM micrograph was adjusted using either a mixed or traditional segmentation algorithm in the Diameter) Segmentation plugin (Hotaling et al., 2015). For each micrograph, the output result that best fit the original was manually determined from 16 possible black and white images. The outlines of segments or pores (pore size area: 0 -infinity $\mu \mathrm{m}^{2}$ ) were determined automatically, and the area $\left(\mu \mathrm{m}^{2}\right)$ of each pore was calculated (Supplementary Material, Figure S3). Outlined areas were visually inspected for detection errors and manually traced using the polygon tool if needed. The mean 2-D porosity for each ossicle (i.e., individual urchin), and the mean porosity and variance for each depth zone ( $n=5$ individual urchins per depth zone) were calculated.

High-resolution micro-computed tomography (HR- $\mu \mathrm{CT})$ was used to explore the spatial variability of porosity within individual ossicles and to obtain more accurate estimations of three-dimensional porosity. Single ossicles from $333 \mathrm{~m}$ and $1,116 \mathrm{~m}$ were selected to represent a broad range in physicochemical environments. Each ossicle was embedded in epoxy and scanned with an isotropic voxel size of $400 \mathrm{~nm}$ at a $40 \mathrm{kV}$ acceleration voltage. The rotation angle and tilt increment were set at $360^{\circ}$ and $0.2^{\circ}$, respectively, using a MicroXCT-200 scanner (Xradia, Pleasanton, CA) at the National Center for Microscopy and Imaging Research facility (University of California, San Diego). Each scan was selected for visualization using Amira software (FEI Visualization Sciences Group, Burlington, MA). Distribution of surface porosity was visualized by creating volume renderings of each ossicle and adjusting the threshold range limits (i.e., average range threshold limits and upper range (low porosity) threshold limits). To quantify 3-D porosity for each sample, a $200-\mu \mathrm{m}$ sided box was haphazardly placed inside the initial scan file, additional volume renderings were created, and the percent porosity was calculated from Material Statistics outputs. 


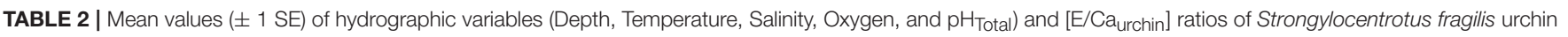
tests separated by depth zone bin.

\begin{tabular}{|c|c|c|c|c|c|c|}
\hline Zone & $\mathbf{n}$ & Depth (m) & Temp $\left({ }^{\circ} \mathrm{C}\right)$ & Salinity & Oxygen $\left(\mu \mathrm{mol} \mathrm{kg}{ }^{-1}\right)$ & $\mathbf{p H}_{\text {Total }}$ \\
\hline Shelf & 24 & $174.2 \pm 10.5$ & $9.44 \pm 0.17$ & $33.98 \pm 0.05$ & $90.39 \pm 8.53$ & $7.69 \pm 0.02$ \\
\hline OLZ & 20 & $362.5 \pm 8.01$ & $8.05 \pm 0.10$ & $34.29 \pm 0.08$ & $33.08 \pm 0.77$ & $7.57 \pm 0.01$ \\
\hline OMZ/LOMZ & 26 & $681.8 \pm 32.4$ & $5.55 \pm 0.19$ & $34.36 \pm 0.01$ & $14.61 \pm 0.71$ & $7.57 \pm 0.06$ \\
\hline \multicolumn{7}{|c|}{ URCHIN ( $\left.\mu \mathrm{mol} \mathrm{mol} \mathrm{Ca}^{-1}\right)$} \\
\hline Zone & $\mathbf{n}$ & Zn & $\mathrm{Ni}$ & Cd & $\mathbf{U}$ & $\mathbf{P}$ \\
\hline Shelf & 24 & $12.66 \pm 1.89$ & $10.566 \pm 0.07$ & $0.98 \pm 0.09$ & $0.22 \pm 0.02$ & $9.46 \pm 1.41$ \\
\hline OLZ & 20 & $8.62 \pm 0.87$ & $10.506 \pm 0.04$ & $0.74 \pm 0.04$ & $0.13 \pm 0.01$ & $1.33 \pm 0.19$ \\
\hline OMZ/LOMZ & 26 & $9.69 \pm 1.48$ & $10.528 \pm 0.09$ & $0.61 \pm 0.07$ & $0.12 \pm 0.01$ & $4.47 \pm 0.64$ \\
\hline \multicolumn{7}{|c|}{ URCHIN (mmol mol $\left.\mathrm{Ca}^{-1}\right)$} \\
\hline Zone & $\mathbf{n}$ & Mg & $\mathrm{Sr}$ & $\mathrm{Fe}$ & & \\
\hline Shelf & 24 & $19.86 \pm 0.22$ & $5.90 \pm 0.04$ & $6.93 \pm 0.12$ & & \\
\hline OLZ & 20 & $19.88 \pm 0.18$ & $5.93 \pm 0.03$ & $7.28 \pm 0.12$ & & \\
\hline OMZ/LOMZ & 26 & $18.49 \pm 0.13$ & $5.79 \pm 0.03$ & $6.94 \pm 0.16$ & & \\
\hline
\end{tabular}

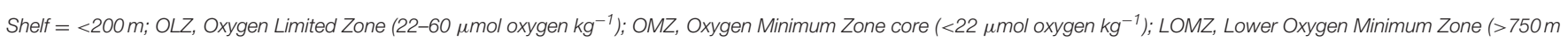
where dissolved oxygen begins to increase).

\section{Statistical Analyses}

To examine the environmental (e.g., depth, temperature, salinity, DO, $\mathrm{pH}_{\text {Total }}$ ) and zonal effects (e.g., Shelf, OLZ, OMZ, and LOMZ) on urchin test size, gonad index, single element concentrations, hardness, stiffness, and porosity, the data were tested for normality using the Shapiro-Wilk test and homogeneity of variances using the Breusch-Pagan test. In each univariate analysis, where assumptions of normality and homoscedasticity were met, parametric tests such as linear regression with hydrographic variables as explanatory factors or one-factor analysis of variance (ANOVA) with depth zone as a factor were employed. If the data violated these assumptions, the Box-Cox power transformation in $\mathrm{R}$ was used to transform the data. If the transformation did not improve normality or homoscedasticity of the data, then non-parametric tests were used. Specifically, Kruskal-Wallis tests were used to compare TLD and gonad index across zones, followed by post hoc Dunn's tests to analyze differences between zones. One-way ANOVAs were employed to compare mechanical properties of ossicles (i.e., hardness, stiffness) and ossicle 2-D porosity across zones, followed by Tukey HSD tests to analyze differences between zones.

Non-metric multidimensional scaling (NMDS) ordinations were employed to evaluate the multi-elemental biomineral composition patterns among urchins collected from different depth zones. Urchin samples were organized and analyzed based on their origin of collection at four depth-, temperature-, salinity-, pH-, and oxygen-related zones (e.g., Shelf, OLZ, OMZ, and LOMZ). Mole fraction ratios of element to calcium were converted to $\mathrm{mmol} \mathrm{mol}^{-1}$ or $\mu \mathrm{mol} \mathrm{mol}{ }^{-1}$ (for standardization purposes) and square-root transformed prior to Bray-Curtis distance similarity matrix calculation using the vegan package (v. 2.4-2) in R (Oksanen et al., 2017). Elements and hydrographic variables were tested for ordination significance based on a permutation test with 999 iterations using the function "envfit" (vegan package) with equally weighted "sites" (i.e., indiv. urchins). Vectors of variables with a significance of $p<0.05$ were scaled relative to their correlation coefficient and plotted onto the 2-D ordination space.

\section{RESULTS}

Multiple fitness-related traits were compared across multiple concomitant environmental gradients to better understand the potential implications of future climate change in a region characterized by expanding low-oxygen, low-pH zones. Large differences were seen across depth zones, with all trait patterns pointing to the model urchin species, Strongylocentrotus fragilis, having the highest fitness in the Shelf zone and lowest in the OMZ. Biomineral elemental composition of calcified test ossicles revealed significant linear relationships of only $\mathrm{Mg}$ and $\mathrm{Sr}$ with some environmental variables (i.e., temperature, oxygen, and salinity).

\section{Urchin Size and Gonad Index}

Urchin test length diameter (TLD) ranged from $22.3-88.1 \mathrm{~mm}$ (Table 1; $\mathrm{n}=656$ indiv.; 53 sites). Mean TLD was significantly different between Shelf, OLZ, and OMZ (Figure 2A; KruskalWallis: $\left.\chi^{2}=111.11, p<0.001\right)$, but not OLZ and LOMZ. The mean TLD of $S$. fragilis in the Shelf zone was $\sim 25 \%$ greater than in the OLZ, $\sim 30 \%$ greater than in the OMZ, and $\sim 15 \%$ greater than in the LOMZ (Dunn's test: $p \leq 0.001$ ). On average, $S$. fragilis TLD in the OMZ (core region) were $\sim 5 \%$ smaller than in the OLZ and $\sim 10 \%$ smaller than in the LOMZ $(p<0.05)$.

Mean gonad index (GI) of $S$. fragilis was significantly different among depth zones (Figure 2B; Kruskal-Wallis: $\chi^{2}=107.35, p<$ $0.001)$. Mean GI in the Shelf zone was $\sim 40 \%$ greater than in the OLZ, $\sim 250 \%$ greater than in the OMZ, and $\sim 60 \%$ greater than in the LOMZ (Dunn's test: $p \leq 0.001$ ). Mean GI in the OMZ was $\sim 60 \%$ lower than in the OLZ and $\sim 55 \%$ lower than in the LOMZ 

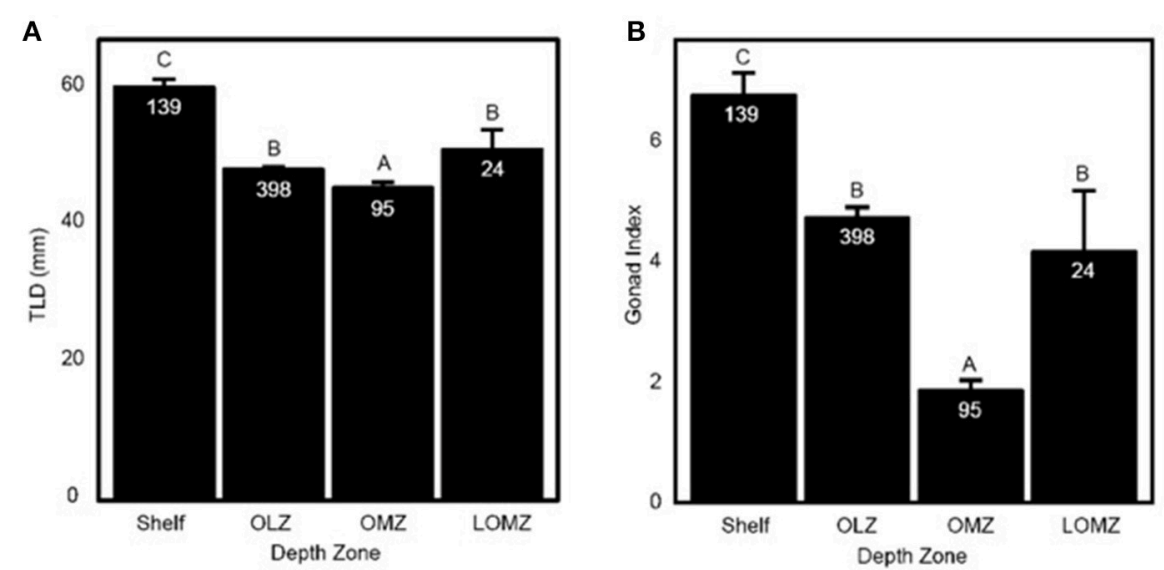

FIGURE 2 | Representation of Strongylocentrotus fragilis traits across depth zones. (A) Total length of diameter (TLD; mm) of tests collected throughout the SCB. (B) Mean Gonad Index (Gl). Error bars are standard errors and numbers in barplots are numbers of dissected urchins ( $N$ ). Shelf $=<200 \mathrm{~m}$; OLZ = Oxygen Limited Zone (22-60 $\mu \mathrm{mol}$ oxygen $\mathrm{kg}^{-1}$ ); OMZ = Oxygen Minimum Zone core ( $<22 \mu \mathrm{mol}$ oxygen $\mathrm{kg}^{-1}$ ); LOMZ = Lower Oxygen Minimum Zone (>900 m where dissolved oxygen begins to increase).

(Dunn's test: $p \leq 0.006$ ). There was no significant difference in mean GI between the OLZ and the LOMZ (Dunn's test: $p=$ 0.12 ). Urchins were collected primarily during summer months (Supplementary Material, Table S1), which minimized the effect of seasonal variability on these results; see Sato et al. (2018) for seasonal changes in S. fragilis reproductive cycle.

\section{Biomineral Element Composition}

For a total of 70 out of 103 samples used in subsequent analyses, each element was detected without being flagged for having greater than $2 \%$ internal precision. The $\mathrm{Sr} / \mathrm{Ca}$ ratio in the calcified test ossicles was positively related to temperature (Figure 3A; Linear Regression: $r^{2}=0.34, p=0.028$ ) and DO (Figure 3B; Linear Regression: $r^{2}=0.41, p=0.014$ ), but not salinity, $\mathrm{pH}$ or depth. $\mathrm{Mg} / \mathrm{Ca}$ ratios of all ossicles were $<0.025$ (Table 2). $\mathrm{Mg} / \mathrm{Ca}$ ratios were positively related to temperature (Figure 3C; Linear Regression: $\left.r^{2}=0.39, p=0.018\right)$ and negatively related to salinity (Figure 3D; Linear Regression: $r^{2}=0.46, p=0.018$ ), but there was no relationship with $\mathrm{DO}, \mathrm{pH}$, or depth. There were no significant relationships of the remaining element to $\mathrm{Ca}$ ratios $(\mathrm{Fe} / \mathrm{Ca}, \mathrm{Zn} / \mathrm{Ca}, \mathrm{Ni} / \mathrm{Ca}, \mathrm{Cd} / \mathrm{Ca}, \mathrm{U} / \mathrm{Ca}$, and $\mathrm{P} / \mathrm{Ca}$ ) with any environmental variables. Mean molar ratios ( \pm 1 s.e.) of all elements to $\mathrm{Ca}$ are shown in Table 2.

There were significant relationships between the ratios of $\mathrm{Fe} / \mathrm{Ca}$ and $\mathrm{Cd} / \mathrm{Ca}$ in tests and in seawater (Figure 4). We found greater $\mathrm{Fe}$ concentration in tests in response to greater $\mathrm{Fe}$ concentrations in seawater (Figure 4A; Linear Regression: $r^{2}=$ 0.99; $p<0.001$ ), and lower Cd concentration in tests in response to greater $\mathrm{Cd}$ concentrations in seawater (Figure 4B; Linear Regression: $\left.r^{2}=0.99 ; p<0.001\right)$. Although similar positive $(\mathrm{Mg}, \mathrm{U}, \mathrm{Ni}$ ) and negative $(\mathrm{Sr}, \mathrm{P}, \mathrm{Zn})$ trends were observed for other elements, these relationships were not significant (Linear Regression: $p>0.05$; Supplemental Material, Figure S4). The partition coefficient $\left(\mathrm{D}_{\mathrm{E}}\right)$ was $>1$ for $\mathrm{Ni}, \mathrm{Zn}, \mathrm{Cd}$ and $\mathrm{Fe}$, and $<1$ for $\mathrm{Mg}, \mathrm{Sr}, \mathrm{P}$, and $\mathrm{U}$ (Figure 4C). For elements with $\mathrm{D}_{\mathrm{E}}>1, \mathrm{D}_{\mathrm{E}}$ was highest in urchins from the Shelf and lowest in urchins from the OMZ.

\section{Test Mechanical Properties}

Mean hardness of skeletal test ossicles ranged from 0.06 to $0.18 \mathrm{GPa}$ (Figure 5A). Ossicles from the Shelf zone were approximately $188 \%$ harder than those in the OMZ and $110 \%$ harder than those collected from the OLZ and the LOMZ

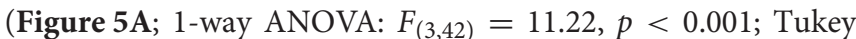
HSD: $p \leq 0.005)$. Mean hardness of OMZ urchin ossicles was $32 \%$ lower than those from the LOMZ, but this was not statistically significant (Figure 5A; Tukey HSD: $p>0.05$ ).

Mean stiffness (i.e., elastic modulus) of test ossicles ranged from 2.69 to $10.10 \mathrm{GPa}$ (Figure 5B). Stiffness values were squareroot transformed, and significant differences were found among depth zones (Figure 5B; 1-way ANOVA: $F_{(3,42)}=17.78, p<$ 0.001). Mean stiffness of the ossicles from Shelf zone was between $140-280 \%$ greater than that of ossicles from the other three depth zones (Figure 5B; Tukey HSD: $p<0.001$ ).

\section{Porosity}

Two-dimensional porosity (\% pore area) of cross sections of test ossicles ranged from $35 \%$ in samples collected from the Shelf to $>45 \%$ in LOMZ samples and differed significantly across depth zones (Figure 5C; 1 -way ANOVA: $F_{(3,15)}=9.143, p=0.001$ ). Mean 2-D porosity of Shelf urchin ossicles was $19 \%$ lower than OMZ urchin ossicles (Tukey HSD: $p=0.004$ ) and 22\% lower than LOMZ urchin ossicles $(p=0.001)$. Consistent with the change in porosity, the mean pore size was significantly different across depth zones (Figure 5D; 1-way ANOVA: $F_{(3,15)}=9.542, p<$ $0.001)$. Mean pore size in the LOMZ was almost double that of the Shelf urchins (Tukey HSD: $p<0.001$ ).

Analysis of HR- $\mu \mathrm{CT}$ scans for 3-D assessment revealed significant variability in porosity across the outer surface and within the sponge-like stereom of the ossicle (Supplementary Material, Figure S5). 3-D porosity analysis from $200-\mu$ m-sided 


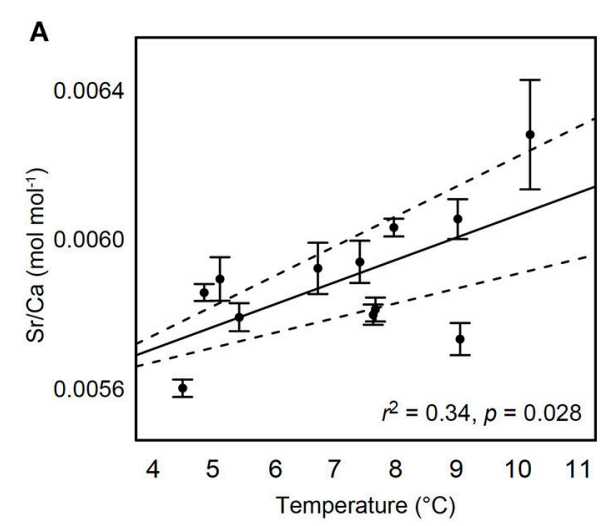

C

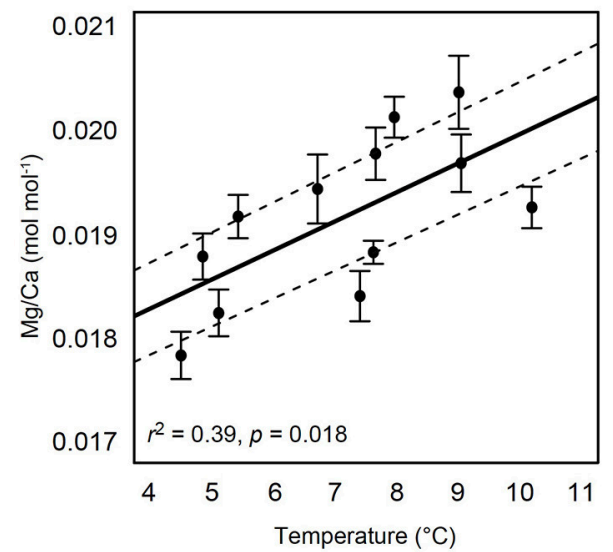

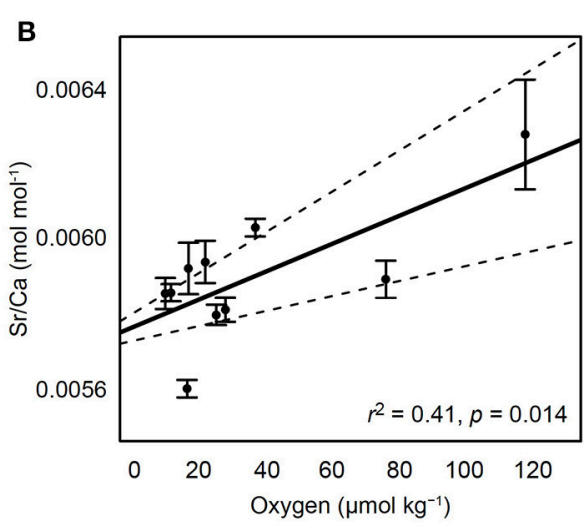

D

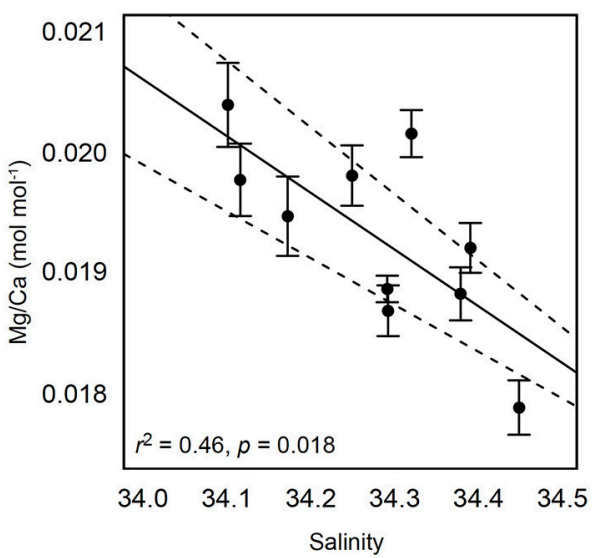

FIGURE 3 | Relationships of test ossicle elemental concentrations and hydrographic variables. Ratios of $\mathrm{Sr} / \mathrm{Ca}\left(\mathrm{mol} \mathrm{mol}{ }^{-1}\right)$ with (A) temperature and (B) dissolved oxygen. Ratios of $\mathrm{Mg} / \mathrm{Ca}\left(\mathrm{mol} \mathrm{mol}^{-1}\right)$ with (C) temperature and (D) salinity. Black solid lines indicate the best fit line result of linear regression. Dashed lines indicate $95 \%$ confidence intervals. Error bars are \pm 1 standard error.

volume renderings of urchins from both $333 \mathrm{~m}$ and $1116 \mathrm{~m}$ exhibited $\sim 80 \%$ pore space compared to the 2 -D porosity estimates of $35-45 \%$ (Figure 5D).

\section{Multivariate Test Properties}

NMDS ordination analysis resulted in significant correlations of multiple elements and mechanical response variables within the 2-D ordination space (Supplementary Material, Figure S6; 2-D stress $=0.08$ ). Magnesium was not correlated with nanohardness as originally hypothesized. Instead, $\mathrm{Sr} / \mathrm{Ca}, \mathrm{Ni} / \mathrm{Ca}$, and the lack of $\mathrm{Cd} / \mathrm{Ca}$ appeared positively correlated with $\mathrm{S}$. fragilis test hardness and stiffness. U/Ca appeared to be positively correlated with pore size and total porosity within the test structure.

\section{DISCUSSION}

Results offer new insights into the evolutionary and ecological consequences of multiple climate change parameters on fitness traits of a model species including its structural properties and potential vulnerability to crushing predators. Sea urchins are generally thought to be vulnerable to the chemical changes in marine systems associated with acidification, and presumed deoxygenation (Dupont et al., 2010; Kroeker et al., 2010; Kurihara et al., 2013), but previous studies have not considered urchins exposed to deeper intermediate waters. In southern California, for example, the upper boundary $\left(60 \mu \mathrm{mol} \mathrm{kg}{ }^{-1}\right)$ of the OLZ has shoaled by as much at $100 \mathrm{~m}$ over the past 25 years (Bograd et al., 2008, 2015). This change coincides with an upslope expansion of deep-water sea urchin species, including the pink sea urchin, Strongylocentrotus fragilis, and an apparent habitat compression for a shallower urchin species, Lytechinus pictus (Sato et al., 2017). The observed shoaling of low oxygen zones coupled with predicted acidification and undersaturation of subsurface waters with respect to calcium carbonate mineral phases (Alin et al., 2012; Gruber et al., 2012; Bograd et al., 2015) present the impetus to better understand the functional implications of multiple climate change drivers on key taxa like $S$. fragilis in southern California. We compared urchin size (test diameter), gonad index, biomineral element composition, material properties (hardness and stiffness), and test microstructure (porosity) of $S$. fragilis across four depth zones (Shelf, OLZ, OMZ, and Lower OMZ). Our results support our hypothesis that $S$. fragilis in the Shelf zone exhibited higher fitness properties compared to those in OLZ, OMZ, and LOMZ depth bins. 
A

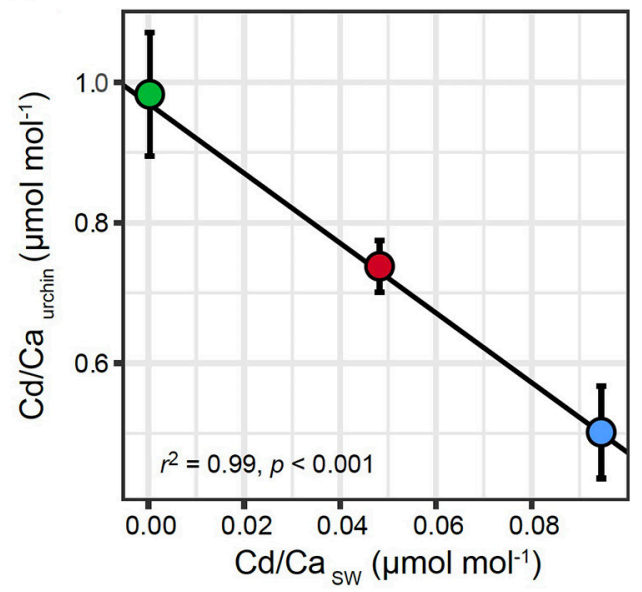

B

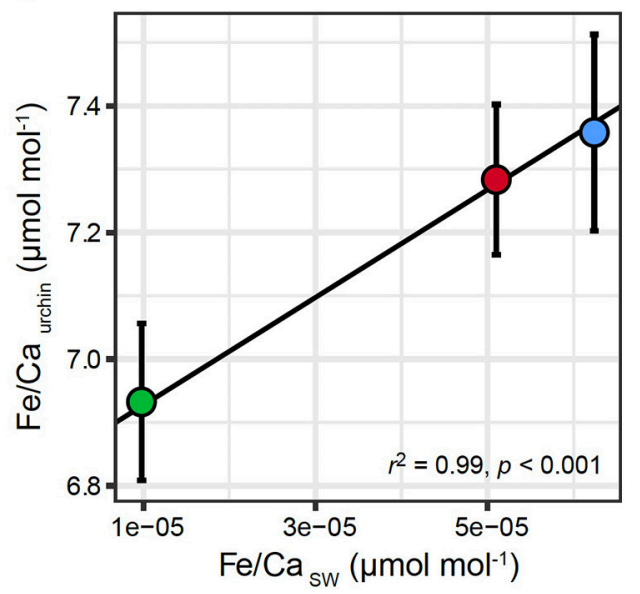

C

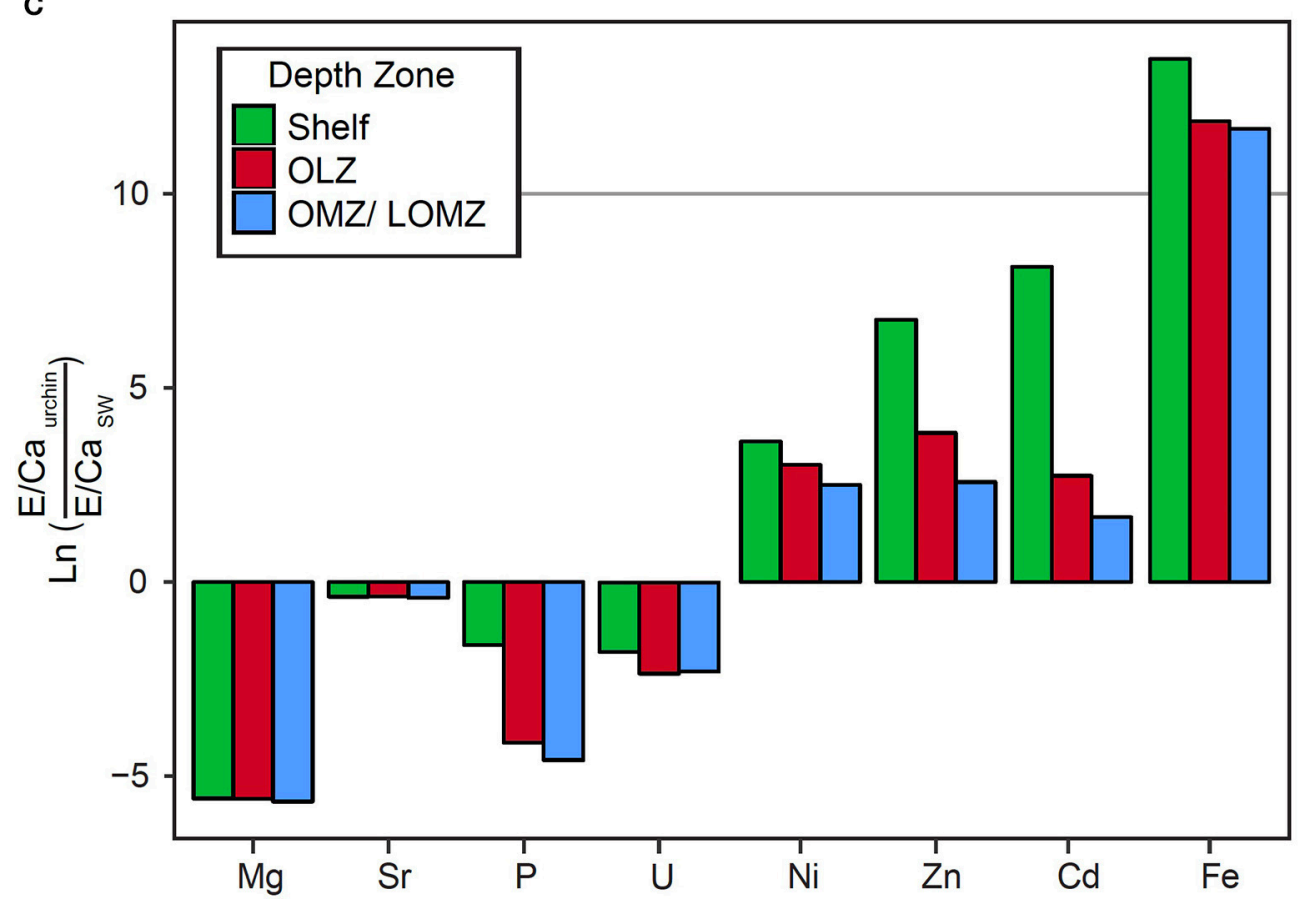

FIGURE 4 | Relationships between element to calcium ratios in Strongylocentrotus fragilis test plates ( $\left.E / \mathrm{Ca}_{\text {urchin }}\right)$ and element to calcium ratios in seawater (E/Casw) within different depth zones. E/Caurchin were averaged across depth bins, Shelf (green), Oxygen Limited Zone (red), and Oxygen Minimum Zone / LOMZ (blue). Black lines indicate significant linear regression relationships which yielded empirical partition coefficients $\left(\mathrm{D}_{\text {metal }}\right)$ for $(\mathbf{A}) \mathrm{Cd}$ and (B) Fe. Error bars indicate \pm 1 standard error. (C) Natural log-transformed ratios of elemental incorporation in Strongylocentrotus fragilis E/Caurchin versus element concentration ratios in seawater E/Casw. $\mathrm{Ln}$ values $>0$ indicate E/Caurchin $>\mathrm{E} / \mathrm{Casw}$. Values $<0$ indicate E/Caurchin $<\mathrm{E} / \mathrm{Casw}$. Elemental concentrations of various elements in seawater (Mg, Sr, P, U, Ni, Zn, $\mathrm{Cd}, \mathrm{Fe}$, and $\mathrm{Ca}$ ) in the upper $1,000 \mathrm{~m}$ of the water column were extracted from Biller and Bruland (2013) and Dr. Kenneth Johnson's Periodic Table of Elements in the Ocean. Available online at: http://www.mbari.org/science/upper-ocean-systems/chemical-sensor-group.

\section{Size and Reproductive Potential}

S. fragilis may respond to unfavorable future acidification and deoxygenation by either shrinking in size (Figure 2A), as seen in other animals (Piersma and Drent, 2003), including S. purpuratus (Ebert, 1967, 1968), by limiting gonad production (Figure 2B), or by growing slower (Sato et al., 2018). Availability of the preferred food, sunken kelp detritus, likely plays an important role in the trait differences seen in S. fragilis from the Shelf compared to other zones (Figures 2, 4). Using remotely operated vehicles (ROVs), Sato et al. (2018) observed aggregations of S. fragilis feeding on giant kelp detritus at depths shallower than $500 \mathrm{~m}$, but no aggregations were seen on sunken detritus deeper than $500 \mathrm{~m}$. Smaller urchins with significantly reduced GI in the OMZ support previous findings of reduced relative 

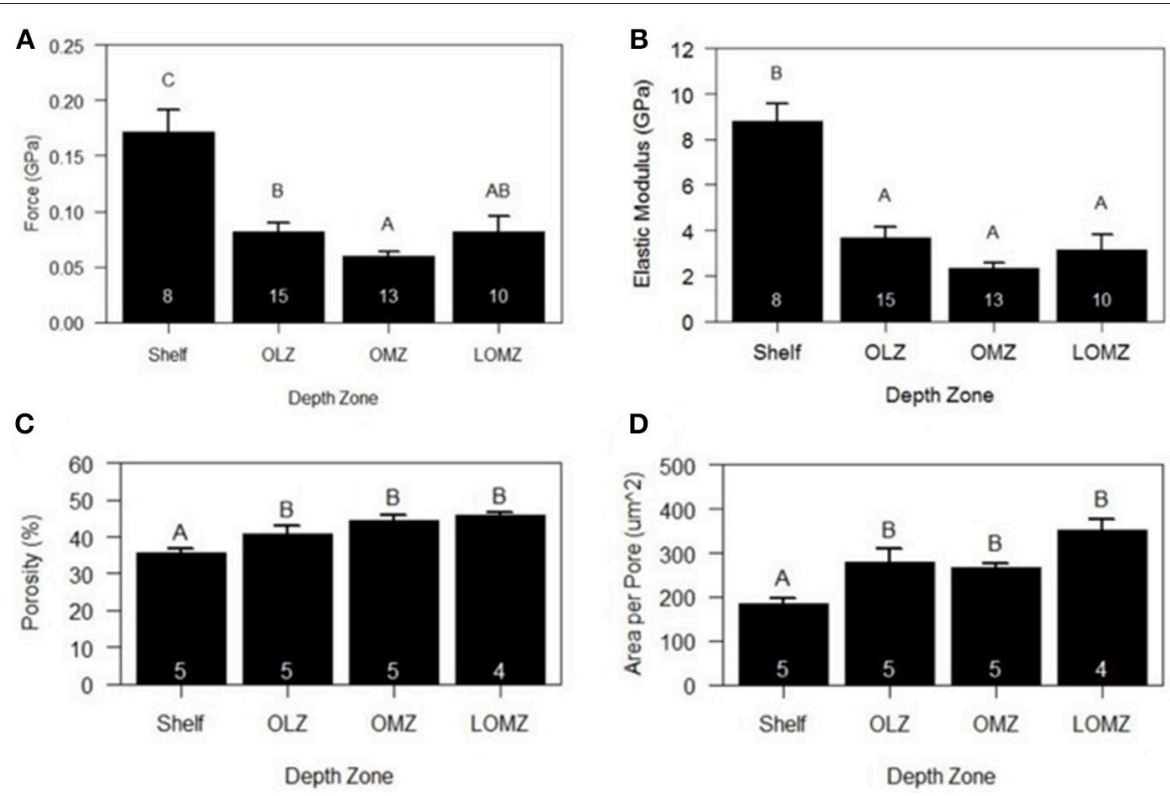

FIGURE 5 | Mean biomechanical and material properties of Strongylocentrotus fragilis across depth zones. (A) Hardness (GPa). (B) Stiffness (i.e., Elastic Modulus) (C) \% Porosity. (D) Area per pore $\left(\mu \mathrm{m}^{2}\right)$. White numbers inside bars indicate number of individual urchin replicates. Errors bars indicate +1 standard error. Shelf $=$ <200 m; OLZ = Oxygen Limited Zone (22-60 $\mu$ mol oxygen $\left.\mathrm{kg}^{-1}\right)$; OMZ = Oxygen Minimum Zone core $\left(<22 \mu \mathrm{mol}\right.$ oxygen kg $\left.{ }^{-1}\right)$; LOMZ = Lower Oxygen Minimum Zone (>900 $\mathrm{m}$ where dissolved oxygen begins to increase).

growth rates (Sato et al., 2018), which is consistent with the theory that increased food availability may mitigate negative impacts on growth and gonad production (Ebert, 1968; Dupont et al., 2013). However, deep-sea urchin food availability remains underrecorded in this region indicating that more data are required to better understand how $S$. fragilis will be impacted by future $\mathrm{OA}$ and deoxygenation.

A subtropical urchin species, Hemicentrotus pulcherrimus, exposed to elevated $p \mathrm{CO}_{2}(1,000 \mu \mathrm{atm})$ for 16 days exhibited an initial suppression of food intake and a subsequent delay in gonad production and reproductive phenology after longerterm exposure to elevated $\mathrm{CO}_{2}$ conditions (Kurihara et al., 2013). Since no effect was found on growth rate or respiration rate, the authors suggested that the reduced feeding could negatively affect the quality of $H$. pulcherrimus eggs (size and nutrient content). Although we did not investigate the quality of $S$. fragilis eggs, it is quite likely that OMZ urchins received less food input in the form of allochthonous kelp than those in the Shelf zone, as reflected by their smaller size and lower gonad index. Furthermore, the gonad index of $S$. fragilis from the OMZ in this study was lower than previously reported GIs measured in urchins from a repeat OLZ station $(\sim 350 \mathrm{~m})$ over 4 years (Sato et al., 2018). Here we found significantly larger individuals with higher gonad indices in the LOMZ compared to the OMZ core, which suggests that physicochemical factors like $\mathrm{pH}$ and oxygen are likely key drivers in gonad production and growth processes.

\section{Microstructure and Biomechanics}

The observed increases in $2-D$ porosity and mean pore size of tests seen at OLZ, OMZ, and LOMZ depths relative to conspecifics from Shelf depths (Figures 5C,D) are consistent with the hypothesis that sublethal effects on form and function may occur under energetically stressful conditions (Todgham and Hofmann, 2009; Byrne et al., 2014). Although recent evidence suggests some urchin species including the congener, S. purpuratus, may have the evolutionary capacity to adapt or acclimatize to OA levels expected under "business-as-usual" $\mathrm{CO}_{2}$ emission scenarios (Kelly et al., 2013; Hofmann et al., 2014), fitness trait responses to $\mathrm{OA}$ and other potential climate change parameters are context-dependent (e.g., species, life-history stage; Dupont et al., 2010; Padilla-Gamiño et al., 2013; Dubois, 2014). Compared to shallow-water urchin species, S. fragilis appears to have a more limited ability to regulate acid-base balance of its extracellular fluids in response to month-long exposure to decreased $\mathrm{pH}_{\text {Total }}(\sim 7.2)$ levels, which were predicted to simulate year 2300 conditions in the OMZ (Taylor et al., 2014). In contrast, a temperate shallow urchin species (Paracentrotus lividus) was shown to regulate extracellular $\mathrm{pH}$ by compensating coelomic fluid acidosis with both bicarbonate and non-bicarbonate buffers (Collard et al., 2013, 2014); and P. lividus exhibited no significant differences in the mechanical properties of its skeletal test after long-term exposure (12 months) to future $p \mathrm{CO}_{2}$ scenarios (Collard et al., 2016).

Regulation of internal $\mathrm{pH}$ for calcification is thought to be energy intensive (McCulloch et al., 2012), and if food availability is limited, energy allocation also might shift away from calcification and growth to other physiological functions (e.g., see Hennige et al. (2015) for cold water corals). Higher 2-D porosity and larger pore sizes of $S$. fragilis in the OLZ, OMZ, and LOMZ compared to those at Shelf depths are consistent 
with previous findings that $\mathrm{pH}$ and $\mathrm{DO}$ are strongly related to growth rate (Sato et al., 2018). Alternatively, the critical proteins, glycoproteins, and polysaccharides responsible for biomineral crystal nucleation may be in higher demand within the organic matrix during $S$. fragilis skeletogenesis in these zones (Hermans et al., 2010; Addadi and Weiner, 2014). Comparative analysis between proteomes of $S$. fragilis and the shallow-water congener, S. purpuratus by Oliver et al. (2010) concluded that genes responsible for skeletal development and sulfur metabolism (e.g., carbohydrate sulfotransferases) were expressed more in S. fragilis relative to $S$. purpuratus. These results provide further evidence that $S$. fragilis is better adapted to potentially grow at deeper, energetically costly depths despite the greater demand to produce precursor macromolecules for skeletogenesis (Mann et al., 2008) and maintain extracellular acid-base regulation of internal fluids (Taylor et al., 2014).

\section{Test Minerology}

Biocalcification rates by echinoderms (e.g., sea urchins, sea stars, brittle stars, crinoids) contribute significantly to calcium carbonate production on a global scale (Lebrato et al., 2010). Some sea urchins, but not all (Presser et al., 2010), produce skeletal tests containing $\sim 12-18 \% \mathrm{~mol}^{2} \mathrm{MgCO}_{3}$ (Chave, 1954; Andersson et al., 2008; Lavigne et al., 2013; Lebrato et al., 2016), which are more soluble than tests with lower $\mathrm{MgCO}_{3}$. S. fragilis skeletal test ossicles collected across all SCB sites spanning multiple environmental conditions, revealed low mean ( \pm 1 s.e.) concentrations of $\mathrm{Mg}(0.019 \pm 0.001 \mathrm{~mol}$ mol Ca ${ }^{-1}$, i.e., $\left.1.9 \% \mathrm{MgCO}_{3}\right)$, which suggests that the $\mathrm{Mg}$ content of their skeletal tests falls in the lower end of values documented for sea urchin species (range: $\sim 0.042-0.19 \mathrm{~mol}$ $\mathrm{Mg}$ mol $\mathrm{Ca}^{-1}$ ) collected from natural environments (see Supplementary Table in Lebrato et al., 2016). Calcite with lower amounts of $\mathrm{Mg}$ is less soluble than other common biogenic mineral phases of calcium carbonate such as aragonite, which is deposited by corals (Andersson and Mackenzie, 2012) and pteropods (Bednaršek et al., 2016, 2017). The low $\mathrm{MgCO}_{3}$ content found in $S$. fragilis tests provides additional support to previous conclusions about their high tolerance to low $\mathrm{pH}$, low oxygen waters in the southern CA OMZ (Sato et al., 2017). The low-Mg calcite may provide S. fragilis potentially higher mineral stability and tolerance to low-pH and low seawater carbonate saturation state conditions (e.g., ocean acidification). Although our findings support this hypothesis, further analyses are required on other species, whole individuals, spines, and early life-history stages to fully characterize the variability of $\mathrm{Mg}$ incorporation (Lavigne et al., 2013; Byrne et al., 2014).

Dissolved metals have been used as paleoceanographic environmental proxies to help reconstruct past seawater conditions (Hönisch and Allen, 2013; Janssen et al., 2014) and in ecology as environmental markers to model dispersal and population connectivity (Levin, 2006; Fodrie et al., 2011). Elements such as Sr, cadmium (Cd), and manganese (Mn), have been used as environmental proxies for seawater temperature, dissolved oxygen, and pH (Marchitto et al., 2000; Russell et al., 2004; Tribovillard et al., 2006; Walther and Limburg, 2012;
Limburg et al., 2015; Supplementary Material, Table S2), but the underlying mechanisms for linking the environmental exposure history of the organism to the boron (B) and uranium (U) content of their carbonate are poorly known (Frieder et al., 2014; Levin et al., 2015). At the same time, some heavy metals (e.g., $\mathrm{Zn}, \mathrm{Cd}$, and nickel $(\mathrm{Ni})$ ) are considered to be toxic to marine organisms in low concentrations (Fairbairn et al., 2011; Chiarelli and Roccheri, 2014; Kanold et al., 2016). Calcification mechanisms in adult echinoids and other calcifiers are poorly understood (see Politi et al., 2004 and Von Euw et al., 2017), and any future attempts at proxy development using calcitic S. fragilis tests will depend on the extent to which S. fragilis controls calcification biologically.

Despite such small variation in $\mathrm{Mg} / \mathrm{Ca}$ (s.d. $=0.5 \%$ ), we detected positive relationships of $\mathrm{Mg}$ in $\mathrm{S}$. fragilis with temperature and salinity (Figures 3C, D) and of $\mathrm{Sr}$ content with temperature and oxygen (Figures 3A,B). Although we used mean environmental values in our analyses, these relationships are consistent with results of previous studies on echinoid urchins and other calcifying taxa (Chave, 1954; Moberly, 1968; Mackenzie et al., 1983; Levin et al., 2015; Williams et al., 2017). The positive linear relationship between $\mathrm{Sr}$ content and mean dissolved oxygen (Figure 3A) is also consistent with the linear relationship between relative growth rate and dissolved oxygen content across the depth range described for S. fragilis in Sato et al. (2018). The important influences of growth rates and other biologically mediated vital effects on $\mathrm{Mg}$ and $\mathrm{Sr}$ incorporation during skeletogenesis confound the development of trace elements as environmental proxies in S. fragilis (Chave, 1954; Weiner and Dove, 2003). However, our ability to detect linear trends of small variations in $\mathrm{Mg} / \mathrm{Ca}$ and $\mathrm{Sr} / \mathrm{Ca}$ over a broad spatial range and environmental conditions combined with trace metal incorporation warrants further hypothesis testing under controlled laboratory conditions.

Partition coefficients $\left(\mathrm{D}_{\mathrm{E}}\right)$ greater than $1(\mathrm{Ni} / \mathrm{Ca}, \mathrm{Zn} / \mathrm{Ca}$, $\mathrm{Cd} / \mathrm{Ca}$, and $\mathrm{Fe} / \mathrm{Ca}$ ) could suggest that $S$. fragilis may actively control the incorporation of these trace metals into the test (Figure 4C). Alternatively, S. fragilis may actively remove these elements from the test organic matrix to avoid the potential lethal effects of toxic dissolved metal ions or molecules (e.g., $\mathrm{Zn}^{2+}$ and $\mathrm{CdCl}^{+}$), which has been demonstrated in other urchin species albeit at likely different environmental concentrations (Fairbairn et al., 2011; Chiarelli and Roccheri, 2014). For these trace metals, higher partition coefficients in urchins from the Shelf relative to those in deeper depth bins may also suggest a decrease in the efficiency of elemental uptake during calcification in unfavorable conditions (Figure 4C). However, the lower partition coefficients in OLZ and OMZ depth bins may support an alternative nonbiological uptake hypothesis, i.e., that foreign ions precipitate inorganically from the calcification fluid as a result of variable growth rates and by extension, calcification rates (Lavigne et al., 2013). Notably, these passive "kinetic effects" of trace elemental incorporation in biogenic calcareous structures are not well understood.

Although the $\mathrm{D}_{\text {Metal }}$ in $S$. fragilis appears to be exceptionally high for several elements (Table 2), it is possible that these could 
be overestimations given chemical observations of significantly higher concentrations of these elements ( $\mathrm{Fe}, \mathrm{Mn}, \mathrm{Co}, \mathrm{Cu}$ ) in the benthic boundary layer where urchins live relative to the adjacent water column (Biller and Bruland, 2013). Low-pH environments can limit the bioavailability of other elements (e.g., $\mathrm{Zn}, \mathrm{Cd}$ ), but the majority of trace metal and acidification studies focus on phytoplankton (Kim et al., 2016). However, the mechanisms of trace metal incorporation during calcification in urchins is largely unexplored. Gaps in knowledge concerning the microenvironments in which soft-sediment urchins grow limit our ability to fully understand how vital effects control incorporation of trace metals into $S$. fragilis tests and by extension, mechanical properties (Naleway et al., 2016) and fitness (Byrne et al., 2014).

The opposing directions of the relationships between $\mathrm{E} / \mathrm{Ca}_{\text {calcite }}$ and $\mathrm{E} / \mathrm{Casw}$ in $\mathrm{Cd}$ and $\mathrm{Fe}$ (Figures $4 \mathrm{~A}, \mathbf{B}$ ) raises questions about why $S$. fragilis differentially incorporates these trace metals into the skeletal test (Milton and Chenery, 2001). The strong negative relationship between hardness and $\mathrm{Cd} / \mathrm{Ca}_{\text {calcite }}$ (Supplementary Material, Figure S6) suggests that $\mathrm{Cd}$ could have a direct or indirect negative effect on the hardness of the calcitic test. The tight coupling between dissolved $\mathrm{Cd}$ and phosphate, $\mathrm{PO}_{4}^{3-}$, is well known in oxygenated waters (>75 $\mu \mathrm{mol} \mathrm{kg} \mathrm{kg}^{-1}$ ), but this coupling breaks down in oxygendeprived zones $\left(<75 \mu \mathrm{mol} \mathrm{\textrm {kg } ^ { - 1 }}\right)$ because Cd sulfide (CdS) precipitates where sulfide is present, especially in OLZ and OMZ sediments (Janssen et al., 2014). S. fragilis calcite from Shelf urchins contains approximately two times more Cd than $\mathrm{OMZ}$ urchins and approximately 30\% more Cd than OLZ urchins (Table 2). Although sulfur was not measured in the urchin calcite, S. fragilis is capable of metabolizing sulfur as demonstrated by positive selection for carbohydrate sulfotransferase genes (Oliver et al., 2010), suggesting low oxygen environments may be indirectly linked to multiple fitness trait responses. However, $S$. fragilis larval ecology, dispersal distances, and gene flow across populations require further investigation to better understand its capacity to adapt to rising acidity and declining oxygen throughout its biogeographic range.

\section{CONCLUSIONS}

The relatively low solubility of calcite with low $\mathrm{Mg}$ content compared to other mineral phases of $\mathrm{CaCO}_{3}$ (e.g., aragonite, high-Mg calcite, amorphous $\mathrm{CaCO}_{3}$ ) may suggest a potential evolutionary strategy selected for in $S$. fragilis to tolerate unfavorable carbonate chemistry conditions (Lebrato et al., 2016). It is possible however, that maintenance of low $\mathrm{Mg}$ calcite $\left(0.02 \mathrm{~mol} \mathrm{~mol}^{-1}\right)$ and calcification in the Oxygen Limited Zone and Oxygen Minimum Zone, occurs at the expense of other fitness-related traits such as size, reproductive potential, and growth (Sato et al., 2018). Although S. fragilis may be more tolerant of future climatic changes than other species, our results suggest that $S$. fragilis is more vulnerable to the future upslope expansion of OMZs and calcium carbonate undersaturated waters than previously thought (Taylor et al.,
2014; Sato et al., 2017). Higher porosity, larger pore sizes, and softer, more pliant/flexible skeletal tests found in persistently low $\mathrm{pH}$ (7.57-7.59) and low dissolved oxygen (13-42 $\mu \mathrm{mol}$ $\mathrm{kg}^{-1}$ ) zones could reduce $S$. fragilis fitness by making them more vulnerable to crushing predators on the slope such as lithodid crabs or predatory fish, which may currently avoid low $\mathrm{pH}$, low oxygen zones. On the other hand, S. fragilis' ability to tolerate these low $\mathrm{pH}$, low oxygen conditions may provide protection from some predators if they do not have the same tolerance.

\section{AUTHOR CONTRIBUTIONS}

KS and LL designed the study, carried out the field work, analyzed the results, and wrote the initial draft of the manuscript. KS, JD, and AA conducted geochemical analyses. KS and JT carried out biomechanics work. KS, MF, J-YJ, and JM conducted microscopy and tomography work. All authors edited manuscript drafts.

\section{ACKNOWLEDGMENTS}

We thank the National Oceanic and Atmospheric Administration (NOAA), SCCWRP, UC Ship Funds, and the California Current Ecosystem Long Term Ecological Research program for the ship time necessary to conduct field work, and the various crew and volunteers who helped KS collect urchins, especially Michael Navarro, Natalya Gallo, and Phil Zerofski. Daniel Jio, Katy Kelsoe, Stephanie Luong, Marissa Mangelli, Jackson Powell, and Ximena Trujillo assisted in the laboratory. We are grateful to Andrew Mehring and Martin Tresguerres for constructive comments on earlier manuscript drafts. Funding was provided by the Tegner Fellowship, Sussman Fellowship, and SIO Education office to KNS. Funding to LAL and KNS was provided by NOAA Grant No. NA14OAR4170075, California Sea Grant College Program Project No. R/SSFS-02 through NOAA's National Sea Grant College Program, U.S. Department of Commerce. JM, MBF and J-YJ acknowledge support from a Multi-University Research Initiative (MURI) through the Air Force Office of Scientific Research of the United States (AFOSR-FA9550-15-1-0009) and a National Science Foundation Biomaterials Program Grant 1507978. This work was performed in part at the San Diego Nanotechnology Infrastructure (SDNI) of UCSD, a member of the National Nanotechnology Coordinated Infrastructure, which is supported by the National Science Foundation (Grant ECCS-1542148). The statements, findings, conclusions and recommendations are those of the authors and do not necessarily reflect the views of California Sea Grant or NOAA.

\section{SUPPLEMENTARY MATERIAL}

The Supplementary Material for this article can be found online at: https://www.frontiersin.org/articles/10.3389/fmars. 2018.00258/full\#supplementary-material 


\section{REFERENCES}

Addadi, L., and Weiner, S. (2014). Biomineralization: mineral formation by organisms. Phys. Scr. 89:098003. doi: 10.1088/0031-8949/89/9/098003

Agaogullari, D., Kel, D., Gökçe, H., Duman, I., Öveçoglu, M. L., Akarsubaşi, A. T., et al. (2012). Bioceramic production from sea urchins. Acta Phys. Pol. A 121, 23-26. doi: 10.12693/APhysPolA.121.23

Alin, S. R., Feely, R. A., Dickson, A. G., Hernández-Ayón, J. M., Juranek, L. W., Ohman, M. D., et al. (2012). Robust empirical relationships for estimating the carbonate system in the southern California current system and application to CalCOFI hydrographic cruise data (2005-2011). J. Geophys. Res. 117:C05033. doi: 10.1029/2011JC007511

Andersson, A. J., and Mackenzie, F. T. (2012). Revisiting four scientific debates in ocean acidification research. Biogeosciences 9, 893-905. doi: $10.5194 /$ bg-9-893-2012

Andersson, A. J., Mackenzie, F. T., and Bates, N. R. (2008). Life on the margin: implications of ocean acidification on $\mathrm{Mg}$-calcite, high latitude and cold-water marine calcifiers. Mar. Ecol. Prog. Ser. 373, 265-273. doi: 10.3354/meps07639

Barry, J. P., Lovera, C., Buck, K. R., Peltzer, E. T., Taylor, J. R., Walz, P., et al. (2014). Use of a free ocean $\mathrm{CO} 2$ enrichment (FOCE) system to evaluate the effects of ocean acidification on the foraging behavior of a deep-sea urchin. Environ. Sci. Technol. 48, 9890-9897. doi: 10.1021/es501603r

Bednaršek, N., Feely, R. A., Tolimieri, N., Hermann, A. J., Siedlecki, S. A., Waldbusser, G. G., et al. (2017). Exposure history determines pteropod vulnerability to ocean acidification along the US West Coast. Sci. Rep. 7, 1-12. doi: 10.1038/s41598-017-03934-z

Bednaršek, N., Harvey, C. J., Kaplan, I. C., Feely, R. A., and MoŽina, J. (2016). Pteropods on the edge: cumulative effects of ocean acidification, warming, and deoxygenation. Prog. Oceanogr. 145, 1-24. doi: 10.1016/j.pocean.2016.04.002

Biller, D. V., and Bruland, K. W. (2013). Sources and distributions of Mn, Fe, $\mathrm{Co}, \mathrm{Ni}, \mathrm{Cu}, \mathrm{Zn}$, and $\mathrm{Cd}$ relative to macronutrients along the central California coast during the spring and summer upwelling season. Mar. Chem. 155, 50-70. doi: 10.1016/j.marchem.2013.06.003

Bograd, S. J., Buil, M. P., Di Lorenzo, E., Castro, C. G., Schroeder, I. D., Anderson, C. R., et al. (2015). Changes in source waters to the Southern California Bight. Deep Sea Res. II Top. Stud. Oceanogr. 112, 42-52. doi: 10.1016/j.dsr2.2014.04.009

Bograd, S. J., Castro, C. G., Di Lorenzo, E., Palacios, D. M., Bailey, H., Gilly, W., et al. (2008). Oxygen declines and the shoaling of the hypoxic boundary in the California Current. Geophys. Res. Lett. 35:L12607. doi: 10.1029/2008GL034185

Breitburg, D., Levin, L. A., Oschlies, A., Grégoire, M., Chavez, F. P., Conley, D. J., et al. (2018). Declining oxygen in the global ocean and coastal waters. Science 359:eaam7240. doi: 10.1126/science.aam 7240

Byrne, M., Smith, A. M., West, S., Collard, M., Dubois, P., Graba-Landry, A., et al. (2014). Warming influences $\mathrm{Mg}^{2+}$ content, while warming and acidification influence calcification and test strength of a sea urchin. Environ. Sci. Technol. 48, 12620-12627. doi: 10.1021/es5017526

Candia Carnevali, M. D., Wilkie, I. C., Lucca, E., Andrietti, F., and Melone, G. (1993). The Aristotle's lantern of the sea-urchin Stylocidaris affinis (Echinoida, Cidaridae): functional morphology of the musculo-skeletal system. Zoomorphology 113, 173-189.

Carrington, E., Waite, J. H., Sarà, G., and Sebens, K. P. (2015). Mussels as a model system for integrative ecomechanics. Ann. Rev. Mar. Sci. 7, 443-469. doi: 10.1146/annurev-marine-010213-135049

Chave, K. E. (1954). Aspects of the Biogeochemistry of magnesium, 1. Calcareous marine organisms. J. Geol. 62, 266-283.

Chiarelli, R., and Roccheri, M. C. (2014). Marine invertebrates as bioindicators of heavy metal pollution. Open J. Met. 4, 93-106. doi: 10.4236/ojmetal.2014.44011

Clarke, F. W., and Wheeler, W. D. (1917). The inorganic constituents of marine constituents of marine invertebrates. U.S. Geol. Surv. 102:56.

Collard, M., Dery, A., Dehairs, F., and Dubois, P. (2014). Euechinoidea and Cidaroidea respond differently to ocean acidification. Comp. Biochem. Physiol. Part A Mol. Integr. Physiol. 174, 45-55. doi: 10.1016/j.cbpa.2014.04.011

Collard, M., Laitat, K., Moulin, L., Catarino, A. I., Grosjean, P., and Dubois, P. (2013). Buffer capacity of the coelomic fluid in echinoderms. Comp. Biochem. Physiol. A Mol. Integr. Physiol. 166, 199-206. doi: 10.1016/j.cbpa.2013. 06.002
Collard, M., Rastrick, S. P. S., Calosi, P., Demolder, Y., Dille, J., Findlay, H. S., et al. (2016). The impact of ocean acidification and warming on the skeletal mechanical properties of the sea urchin Paracentrotus lividus from laboratory and field observations. ICES J. Mar. Sci. 73, 727-738. doi: 10.1093/icesjms/fst176

Denny, M., Daniel, T., and Koehl, M. (1985). Mechanical limits to size in waveswept organisms. Ecol. Monogr. 55, 69-102.

Des Roches, S., Post, D. M., Turley, N. E., Bailey, J. K., Hendry, A. P., Kinnison, M. T., et al. (2018). The ecological importance of intraspecific variation. Nat. Ecol. Evol. 2, 57-64. doi: 10.1038/s41559-017-0402-5

deVries, M. S., Webb, S. J., Tu, J., Cory, E., Morgan, V., Sah, R. L., et al. (2016). Stress physiology and weapon integrity of intertidal mantis shrimp under future ocean conditions. Sci. Rep. 6, 1-15. doi: 10.1038/srep38637

Diaz, R. J., and Rosenberg, R. (2008). Spreading dead zones and consequences for marine ecosystems. Science 321, 926-929. doi: 10.1126/science.1156401

Dickson, A. G. (1990). Standard potential of the reaction: $\mathrm{AgCl}_{(\mathrm{s})}+1 / 2 \mathrm{H}_{2(\mathrm{~g})}$ $=\mathrm{Ag}_{(\mathrm{s})}+\mathrm{HCl}_{(\mathrm{aq})}$, and the standard acidity constant of the ion $\mathrm{HSO}_{4}^{-}$in synthetic sea water from 273.15 to $318.15 \mathrm{~K}$. J. Chem. Thermodyn. 22, 113-127. doi: 10.1016/0021-9614(90)90074-Z

Dickson, A. G., Sabine, C. L., and Christian, J. R., (eds.). (2007). Guide to Best Practices for Ocean $\mathrm{CO}_{2}$ Measurements. 3rd Edn. Sidney, BC: PICES Special Edition.

Dubois, P. (2014). The skeleton of postmetamorphic echinoderms in a changing world. Biol. Bull. 226, 223-236. doi: 10.1086/BBLv226n3p223

Dupont, S., Dorey, N., Stumpp, M., Melzner, F., and Thorndyke, M. (2013). Long-term and trans-life-cycle effects of exposure to ocean acidification in the green sea urchin Strongylocentrotus droebachiensis. Mar. Biol. 160, 1835-1843. doi: 10.1007/s00227-012-1921-x

Dupont, S., Ortega-Martínez, O., and Thorndyke, M. (2010). Impact of near-future ocean acidification on echinoderms. Ecotoxicology 19, 449-462. doi: 10.1007/s10646-010-0463-6

Ebert, T. A. (1967). Negative growth and longevity in the purple sea urchin Strongylocentrotus purpuratus (Stimpson). Science 157, 557-558.

Ebert, T. A. (1968). Growth rates of the sea urchin Strongylocentrotus purpuratus related to food availability and spine abrasion. Ecology 49, 1075-1091. doi: $10.2307 / 1934491$

Fabian, D., and Flatt, T. (2012). Life history evolution. Nat. Educ. Knowl. 3:24.

Fairbairn, E. A., Keller, A. A., Mädler, L., Zhou, D., Pokhrel, S., and Cherr, G. N. (2011). Metal oxide nanomaterials in seawater: linking physicochemical characteristics with biological response in sea urchin development. J. Hazard. Mater. 192, 1565-1571. doi: 10.1016/j.jhazmat.2011.06.080

Feely, R. A., Sabine, C. L., Hernandez-Ayon, J. M., Ianson, D., and Hales, B. (2008). Evidence for upwelling of corrosive "acidified" water onto the continental shelf. Science 320, 1490-1492. doi: 10.1126/science.1155676

Fodrie, F. J., Becker, B. J., Levin, L. A., Gruenthal, K., and McMillan, P. (2011). Connectivity clues from short-term variability in settlement and geochemical tags of mytilid mussels. J. Sea Res. 65, 141-150. doi: 10.1016/j.seares.2010.09.001

Frank, M., Naleway, S., Jung, J.-Y., Wirth, T., Cheung, C., Loera, F., et al. (2015). A protocol for bioinspired design: a ground sampler based on sea urchin jaws. $J$. Vis. Exp. 110:e53554. doi: 10.3791/53554

Frieder, C. A., Gonzalez, J. P., and Levin, L. A. (2014). Uranium in larval shells as a barometer of molluscan ocean acidification exposure. Environ. Sci. Technol. 48, 6401-6408. doi: 10.1021/es500514j

Gallo, N. D., and Levin, L. A. (2016). Fish ecology and evolution in the world's oxygen minimum zones and implications of ocean deoxygenation. Adv. Mar. Biol. 74, 117-198. doi: 10.1016/bs.amb.2016.04.001

Gaylord, B., Hill, T. M., Sanford, E., Lenz, E. A., Jacobs, L. A., Sato, K. N., et al. (2011). Functional impacts of ocean acidification in an ecologically critical foundation species. J. Exp. Biol. 214, 2586-2594. doi: 10.1242/jeb.055939

Gilly, W. F., Beman, J. M., Litvin, S. Y., and Robison, B. H. (2013). Oceanographic and biological effects of shoaling of the oxygen minimum zone. Ann. Rev. Mar. Sci. 5, 393-420. doi: 10.1146/annurev-marine-120710-100849

Gooday, A. J., Bett, B. J., Escobar, E., Ingole, B., Levin, L. A., Neira, C., et al. (2010). Habitat heterogeneity and its influence on benthic biodiversity in oxygen minimum zones. Mar. Ecol. 31, 125-147. doi: $10.1111 /$ j.1439-0485.2009.00348.x 
Gruber, N. (2011). Warming up, turning sour, losing breath: ocean biogeochemistry under global change. Philos. Trans. R. Soc. London A Math. Phys. Eng. Sci. 369, 1980-1996. doi: 10.1098/rsta.2011.0003

Gruber, N., Hauri, C., Lachkar, Z., Loher, D., Frolicher, T. L., and Plattner, G. K. (2012). Rapid progression of ocean acidification in the California Current System. Science 337, 220-223. doi: 10.1126/science.1216773

Helly, J. J., and Levin, L. A. (2004). Global distribution of naturally occurring marine hypoxia on continental margins. Deep. Res. Part I Oceanogr. Res. Pap. 51, 1159-1168. doi: 10.1016/j.dsr.2004.03.009

Hennige, S. J., Wicks, L. C., Kamenos, N. A., Perna, G., Findlay, H. S., and Roberts, J. M. (2015). Hidden impacts of ocean acidification to live and dead coral framework. Proc. R. Soc. B Biol. Sci. 282:20150990. doi: 10.1098/rspb.2015.0990

Hermans, J., Borremans, C., Willenz, P., Andre, L., and Dubois, P. (2010). Temperature, salinity and growth rate dependences of $\mathrm{Mg} / \mathrm{Ca}$ and $\mathrm{Sr} / \mathrm{Ca}$ ratios of the skeleton of the sea urchin Paracentrotus lividus (Lamarck): an experimental approach. Mar. Biol. 157, 1293-1300. doi: 10.1007/s00227-010-1409-5

Hofmann, G. E., Evans, T. G., Kelly, M. W., Padilla-Gamiño, J. L., Blanchette, C. A., Washburn, L., et al. (2014). Exploring local adaptation and the ocean acidification seascape - studies in the California Current Large Marine Ecosystem. Biogeosciences 11, 1053-1064. doi: 10.5194/bg-11-1053-2014

Hönisch, B., and Allen, K. A. (2013). "Paleoceanography, physical and chemical proxies: Carbon Cycle Proxies $\left(\delta_{11} \mathrm{~B}, \delta_{13} \mathrm{C}_{\text {calcite }}, \delta_{13} \mathrm{C}_{\text {organic }}\right.$, Shell Weights, $\mathrm{B} / \mathrm{Ca}, \mathrm{U} / \mathrm{Ca}, \mathrm{Zn} / \mathrm{Ca}, \mathrm{Ba} / \mathrm{Ca})$," in Encyclopedia of Quaternary Science 849-858. doi: 10.1016/B978-0-444-53643-3.00288-0

Hotaling, N. A., Bharti, K., Kriel, H., and Simon, C. G. (2015). DiameterJ: a validated open source nanofiber diameter measurement tool. Biomaterials 61, 327-338. doi: 10.1016/j.biomaterials.2015.05.015

Janssen, D. J., Conway, T. M., John, S. G., Christian, J. R., Kramer, D. I., Pedersen, T. F., et al. (2014). Undocumented water column sink for cadmium in open ocean oxygen-deficient zones. Proc. Natl. Acad. Sci. U S A. 111, 6888-6893. doi: 10.1073/pnas.1402388111

Kanold, J. M., Wang, J., Brümmer, F., and Siller, L. (2016). Metallic nickel nanoparticles and their effect on the embryonic development of the sea urchin Paracentrotus lividus. Environ. Pollut. 212, 224-229. doi: 10.1016/j.envpol.2016.01.050

Kelly, M. W., Padilla-Gamiño, J. L., and Hofmann, G. E. (2013). Natural variation and the capacity to adapt to ocean acidification in the keystone sea urchin Strongylocentrotus purpuratus. Glob. Chang. Biol. 19, 2536-2546. doi: $10.1111 /$ gcb. 12251

Kim, J.-M., Baars, O., and Morel, F. M. M. (2016). The effect of acidifcation on the bioavailability and electrochemical lability of zinc in seawater. Philos. Trans. $R$. Soc. A Math. Phys. Eng. Sci. 374:20150296. doi: 10.1098/rsta.2015.0296

Kroeker, K. J., Kordas, R. L., Crim, R. N., and Singh, G. G. (2010). Meta-analysis reveals negative yet variable effects of ocean acidification on marine organisms. Ecol. Lett. 13, 1419-1434. doi: 10.1111/j.1461-0248.2010.01518.x

Kroeker, K. J., Sanford, E., Rose, J. M., Blanchette, C. A., Chan, F., Chavez, F. P., et al. (2016). Interacting environmental mosaics drive geographic variation in mussel performance and predation vulnerability. Ecol. Lett., 771-779. doi: 10.1111 /ele.12613

Kuklinski, P., and Taylor, P. D. (2009). Mineralogy of Arctic bryozoan skeletons in a global context. Facies 55, 489-500. doi: 10.1007/s10347-009-0179-3

Kurihara, H., Yin, R., Nishihara, G. N., Soyano, K., and Ishimatsu, A. (2013). Effect of ocean acidification on growth, gonad development and physiology of the sea urchin Hemicentrotus pulcherrimus. Aquat. Biol. 18, 281-292. doi: $10.3354 / \mathrm{ab} 00510$

Lack, D. (1947). The significance of clutch size. Ibis 89, 302-352.

Lavigne, M., Hill, T. M., Sanford, E., Gaylord, B., Russell, A. D., Lenz, E. A., et al. (2013). The elemental composition of purple sea urchin (Strongylocentrotus purpuratus) calcite and potential effects of $\mathrm{pCO}_{2}$ during early life stages. Biogeosciences 10, 3465-3477. doi: 10.5194/bg-10-3465-2013

Lebrato, M., Andersson, A. J., Ries, J. B., Aronson, R. B., Lamare, M. D., Koeve, W., et al. (2016). Benthic marine calcifiers coexist with $\mathrm{CaCO}_{3}$ undersaturated seawater worldwide. Global Biogeochem. Cycles 30, 1038-1053. doi: 10.1002/2015GB005260

Lebrato, M., Iglesias-Rodriguez, D., Feely, R. A., Greeley, D., Jones, D. O. B., Suarez-Bosche, N., et al. (2010). Global contribution of echinoderms to the marine carbon cycle: $\mathrm{CaCO}_{3}$ budget and benthic compartments. Ecol. Monogr. 80, 441-467. doi: 10.1890/09-0553.1

Levin, L. A. (2003). "Oxygen minimum zone benthos: adaptation and community response to hypoxia," in Oceanogr. Mar. Biol. Ann. Rev. Vol. 41, (London: Aberdeen University Press/Allen \& Unwin), 1-45.

Levin, L. A. (2006). Recent progress in understanding larval dispersal: new directions and digressions. Integr. Comp. Biol. 46, 282-297. doi: 10.1093/icb/icj024

Levin, L. A. (2018). Manifestation, drivers, and emergence of open ocean deoxygenation. Ann. Rev. Mar. Sci. 10, 17.1-17.32. doi: 10.1146/annurev-marine-121916-063359

Levin, L. A., Hönisch, B., and Frieder, C. A. (2015). Geochemical proxies for estimating faunal exposure to ocean acidification. Oceanography 28, 62-73. doi: 10.5670/oceanog.2015.32

Levin, L. A., and Sibuet, M. (2012). Understanding continental margin biodiversity: a new imperative. Ann. Rev. Mar. Sci. 4, 79-112. doi: 10.1146/annurev-marine-120709-142714

Limburg, K. E., Walther, B. D., Lu, Z., Jackman, G., Mohan, J., Walther, Y., et al. (2015). In search of the dead zone: use of otoliths for tracking fish exposure to hypoxia. J. Mar. Syst. 141, 167-178. doi: 10.1016/j.jmarsys.2014.02.014

Lohrer, A. M., Thrush, S. F., Hunt, L., Hancock, N., and Lundquist, C. (2005). Rapid reworking of subtidal sediments by burrowing spatangoid urchins. J. Exp. Mar. Bio. Ecol. 321, 155-169. doi: 10.1016/j.jembe.2005.02.002

Lowder, K. B., Allen, M. C., Day, J. M. D., Deheyn, D. D., and Taylor, J. R. A. (2017). Assessment of ocean acidification and warming on the growth, calcification, and biophotonics of a California grass shrimp. ICES J. Mar. Sci. 74, 1150-1158. doi: 10.1093/icesjms/fsw246

Lueker, T. J., Dickson, A. G., and Keeling, C. D. (2000). Ocean $\mathrm{pCO}_{2}$ calculated from dissolved inorganic carbon, alkalinity, and equations for $K_{1}$ and $K_{2}$ : validation based on laboratory measurements of $\mathrm{CO}_{2}$ in gas and seawater at equilibrium. Mar. Chem. 70, 105-119. doi: 10.1016/S0304-4203(00)00022-0

Ma, Y., Aichmayer, B., Paris, O., Fratzl, P., Meibom, A., Metzler, R. A., et al. (2009). The grinding tip of the sea urchin tooth exhibits exquisite control over calcite crystal orientation and Mg distribution. Proc. Natl. Acad. Sci. U S A. 106, 6048-6053. doi: 10.1073/pnas.0810300106

Mackenzie, F. T., Bischoff, W. D., Bishop, F. C., Loijens, M., Schoonmaker, J., and Wollast, R. (1983). "Mg-calcites: low temperature occurrence, solubility and solid-solution behavior," in Reviews in Mineralogy, Carbonates: Mineralogy and Chemistry, ed. R. J. Reeder (Washington, DC: Mineralogical Society of America), 97-143.

MacLean, S. A., and Beissinger, S. R. (2017). Species' traits as predictors of range shifts under contemporary climate change: a review and meta-analysis. Glob. Chang. Biol. 23, 4094-4105. doi: 10.1111/gcb.13736

Mann, K., Poustka, A., and Mann, M. (2008). The sea urchin (Strongylocentrotus purpuratus) test and spine proteomes. Proteome Sci. 6:22. doi: 10.1016/j.ydbio.2006.07.044

Marchitto, T. M., Curry, W. B., and Oppo, D. W. (2000). Zinc concentrations in benthic foraminfera reflect seawater chemistry. Paleoceanography 15, 299-306. doi: 10.1029/1999PA000420

McCulloch, M., Trotter, J., Montagna, P., Falter, J., Dunbar, R., Freiwald, A., et al. (2012). Resilience of cold-water scleractinian corals to ocean acidification: boron isotopic systematics of $\mathrm{pH}$ and saturation state up-regulation. Geochim. Cosmochim. Acta 87, 21-34. doi: 10.1016/j.gca.2012.03.027

Meyers, M. A., Chen, P.-Y., Lin, A. Y.-M., and Seki, Y. (2008). Biological materials: structure and mechanical properties. Prog. Mater. Sci. 53, 1-206. doi: 10.1016/j.pmatsci.2007.05.002

Milton, D. A., and Chenery, S. R. (2001). Sources and uptake of trace metals in otoliths of juvenile barramundi (Lates calcarifer). J. Exp. Mar. Bio. Ecol. 264, 47-65. doi: 10.1016/S0022-0981(01)00301-X

Moberly, R. (1968). Composition of magnesian calcites of algae and pelecypods by electron microprobe analysis. Sedimentology 11, 61-82.

Moffitt, S. E., Moffitt, R. A., Sauthoff, W., Davis, C. V., Hewett, K., and Hill, T. M. (2015). Paleoceanographic insights on recent oxygen minimum zone expansion: lessons for modern oceanography. PLoS ONE 10:e0115246. doi: 10.1371/journal.pone.0115246

Morse, J. W., Andersson, A. J., and Mackenzie, F. T. (2006). Initial responses of carbonate-rich shelf sediments to rising atmospheric $\mathrm{pCO}_{2}$ and "ocean 
acidification": role of high Mg-calcites. Geochim. Cosmochim. Acta 70, 5814-5830. doi: 10.1016/j.gca.2006.08.017

Moureaux, C., Pérez-Huerta, A., Compère, P., Zhu, W., Leloup, T., Cusack, M., et al. (2010). Structure, composition and mechanical relations to function in sea urchin spine. J. Struct. Biol. 170, 41-49. doi: 10.1016/j.jsb.2010.01.003

Naleway, S. E., Taylor, J. R. A., Porter, M. M., Meyers, M. A., and McKittrick, J. (2016). Structure and mechanical properties of selected protective systems in marine organisms. Mater. Sci. Eng. C Mater. Biol. Appl. 59, 1143-1167. doi: 10.1016/j.msec.2015.10.033

Nam, S., Takeshita, Y., Frieder, C. A., Martz, T., and Ballard, J. (2015). Seasonal advection of pacific equatorial water alters oxygen and $\mathrm{pH}$ in the Southern California Bight. J. Geophys. Res. Ocean. 120, 5387-5399. doi: 10.1002/2015JC010859

Oksanen, J., Blanchet, F. G., Friendly, M., Kindt, R., Legendre, P., McGlinn, D., et al. (2017). vegan: Community Ecology Package. R Package Version 2.4-2. Available online at: https://cran.r-project.org/package=vegan.

Oliver, T. A., Garfield, D. A., Manier, M. K., Haygood, R., Wray, G. A., and Palumbi, S. R. (2010). Whole-genome positive selection and habitat-driven evolution in a shallow and a deep-sea urchin. Genome Biol. Evol. 2, 800-814. doi: $10.1093 /$ gbe/evq063

Padilla-Gamiño, J. L., Kelly, M. W., Evans, T. G., and Hofmann, G. E. (2013). Temperature and $\mathrm{CO}_{2}$ additively regulate physiology, morphology and genomic responses of larval sea urchins, Strongylocentrotus purpuratus. Proc. $R$. Soc. B 280:20130155. doi: 10.1098/rspb.2013.0155

Pearse, J. S. (2006). Ecological role of purple sea urchins. Science 314, 940-941. doi: $10.1126 /$ science. 1131888

Piersma, T., and Drent, J. (2003). Phenotypic flexibility and the evolution of organismal design. Trends Ecol. Evol. 18, 228-233. doi: 10.1016/S0169-5347(03)00036-3

Politi, Y., Arad, T., Klein, E., Weiner, S., and Addadi, L. (2004). Sea urchin spine calcite forms via a transient amorphous calcium carbonate phase. Science 306, 1161-1164. doi: 10.1126/science.1102289

Presser, V., Gerlach, K., Vohrer, A., Nickel, K. G., and Dreher, W. F. (2010). Determination of the elastic modulus of highly porous samples by nanoindentation: a case study on sea urchin spines. J. Mater. Sci. 45, 2408-2418. doi: $10.1007 /$ s10853-010-4208-y

Reich, M., and Smith, A. B. (2009). Origins and biomechanical evolution of teeth in echinoids and their relatives. Palaeontology 52, 1149-1168. doi: 10.1111/j.1475-4983.2009.00900.x

Reusch, T. B. (2014). Climate change in the oceans: evolutionary versus phenotypically plastic responses of marine animals and plants. Evol. Appl. 7, 104-122. doi: 10.1111/eva.12109

Russell, A. D., Hönisch, B., Spero, H. J., and Lea, D. W. (2004). Effects of seawater carbonate ion concentration and temperature on shell $\mathrm{U}, \mathrm{Mg}$, and $\mathrm{Sr}$ in cultured planktonic foraminifera. Geochim. Cosmochim. Acta 68, 4347-4361. doi: 10.1016/j.gca.2004.03.013

Sato, K. N., Levin, L. A., and Schiff, K. (2017). Habitat compression and expansion of sea urchins in response to changing climate conditions on the California continental shelf and slope (1994-2013). Deep Sea Res. II Top. Stud. Oceanogr. 137, 377-389. doi: 10.1016/j.dsr2.2016.08.012

Sato, K. N., Powell, J., Rudie, D., and Levin, L. A. (2018). Evaluating the promise and pitfalls of a potential climate change-tolerant sea urchin fishery in southern California. ICES J. Mar. Sci. 75, 1029-1041. doi: 10.1093/icesjms/fsx225

Schmidtko, S., Stramma, L., and Visbeck, M. (2017). Decline in global oceanic oxygen content during the past five decades. Nature 542, 335-339. doi: 10.1038/nature21399

Schneider, C. A., Rasband, W. S., and Eliceiri, K. W. (2012). NIH Image to Image): 25 years of image analysis. Nat. Methods 9, 671-675. doi: 10.1038/nmeth.2089

Smith, C. C., and Fretwell, S. D. (1974). The optimal balance between size and number of offspring. Am. Nat. 108, 499-506.

Sperling, E. A., Frieder, C. A., and Levin, L. A. (2016). Biodiversity response to natural gradients of multiple stressors on continental margins. Proc. R. Soc. Lond. B Biol. Sci. 283:20160637. doi: 10.1098/rspb.2016.0637

Stramma, L., Schmidtko, S., Levin, L. A., and Johnson, G. C. (2010). Ocean oxygen minima expansions and their biological impacts. Deep Sea Res. I Oceanogr. Res. Pap. 57, 587-595. doi: 10.1016/j.dsr.2010.01.005

Sumich, J. L., and McCauley, J. E. (1973). Growth of a sea urchin, Allocentrotus fragilis, off the Oregon coast. Coast. Pacific Sci. 27, 156-167.
Sunday, J. M., Calosi, P., Dupont, S., Munday, P. L., Stillman, J. H., and Reusch, T. B. (2014). Evolution in an acidifying ocean. Trends Ecol. Evol. 29, 117-125. doi: 10.1016/j.tree.2013.11.001

Swezey, D. S., Bean, J. R., Hill, T. M., Gaylord, B., Ninokawa, A. T., and Sanford, E. (2017a). Plastic responses of bryozoans to ocean acidification. J. Exp. Biol. 220, 4399-4409. doi: 10.1242/jeb.163436

Swezey, D. S., Bean, J. R., Ninokawa, A. T., Hill, T. M., Gaylord, B., and Sanford, E. (2017b). Interactive effects of temperature, food and skeletal mineralogy mediate biological responses to ocean acidification in a widely distributed bryozoan. Proc. R. Soc. B 284, 20162349. doi: 10.1098/rspb.2016. 2349

Takeshita, Y., Frieder, C. A., Martz, T. R., Ballard, J. R., Feely, R. A., Kram, S., et al. (2015). Including high-frequency variability in coastal ocean acidification projections. Biogeosciences 12, 5853-5870. doi: 10.5194/bg-12-5853-2015

Taylor, J. R., Gilleard, J. M., Allen, M. C., and Deheyn, D. D. (2015). Effects of $\mathrm{CO}_{2}$ induced $\mathrm{pH}$ reduction on the exoskeleton structure and biophotonic properties of the shrimp Lysmata californica. Sci. Rep. 5:10608. doi: 10.1038/srep10608

Taylor, J. R., Lovera, C., Whaling, P. J., Buck, K. R., Pane, E. F., and Barry, J. P. (2014). Physiological effects of environmental acidification in the deep-sea urchin Strongylocentrotus fragilis. Biogeosciences 11, 1413-1423. doi: 10.5194/bg-11-1413-2014

Thompson, B., Tsukada, D., and Laughlin, J. (1993). Megabenthic assemblages of coastal shelves, slopes, and basins off southern California. Bull. South. Calif. Acad. Sci. 92, 25-42.

Todgham, A. E., and Hofmann, G. E. (2009). Transcriptomic response of sea urchin larvae Strongylocentrotus purpuratus to $\mathrm{CO}_{2}$-driven seawater acidification. J. Exp. Biol. 212, 2579-2594. doi: 10.1242/jeb.032540

Tribovillard, N., Algeo, T. J., Lyons, T., and Riboulleau, A. (2006). Trace metals as paleoredox and paleoproductivity proxies: an update. Chem. Geol. 232, 12-32. doi: 10.1016/j.chemgeo.2006.02.012

Von Euw, S., Zhang, Q., Manichev, V., Murali, N., Gross, J., Feldman, L. C., et al. (2017). Biological control of aragonite formation in stony corals. Science 356 933-938. doi: 10.1126/science.aam6371

Walter, L. M., and Morse, J. W. (1984). Reactive surface area of skeletal carbonates during dissolution: effect of grain size. J. Sediment. Res. 54, 1081-1090.

Walther, B. D., and Limburg, K. E. (2012). The use of otolith chemistry to characterize diadromous migrations. J. Fish Biol. 81, 796-825. doi: 10.1111/j.1095-8649.2012.03371.x

Walther, S. M., Williams, J. P., Latker, A., Cadien, D. B., Diehl, D. W., Miller, E., et al. (2017). Southern California Bight 2013 Regional Monitoring Program: Volume VIII. Demersal Fishes and Megabenthic Invertebrates. South. Calif. Coast. Water Res. Proj. Costa Mesa, CA.

Wang, R. Z., Addadi, L., and Weiner, S. (1997). Design strategies of sea urchin teeth: structure, composition, and micromechanical relations to function. Philos. Trans. R. Soc. B 352, 469-480.

Weiner, S., and Dove, P. M. (2003). An overview of biomineralization processes and the problem of the vital effect. Rev. Mineral. Geochemistry 54, 1-29. doi: 10.2113/0540001

Williams, B., Halfar, J., Delong, K. L., Smith, E., Steneck, R., Lebednik, P. A., et al. (2017). North Pacific twentieth century decadal-scale variability is unique for the past 342 years. Geophys. Res. Lett. 44, 3761-3769. doi: $10.1002 / 2017$ GL073138

Ziveri, P., Passaro, M., Incarbona, A., Milazzo, M., Rodolfo-Metalpa, R., and HallSpencer, J. M. (2014). Decline in coccolithophore diversity and impact on coccolith morphogenesis along a natural $\mathrm{CO}_{2}$ gradient. Biol. Bull. 226, 282-290. doi: 10.1086/BBLv226n3p282

Conflict of Interest Statement: The authors declare that the research was conducted in the absence of any commercial or financial relationships that could be construed as a potential conflict of interest.

Copyright (C) 2018 Sato, Andersson, Day, Taylor, Frank, Jung, McKittrick and Levin This is an open-access article distributed under the terms of the Creative Commons Attribution License (CC BY). The use, distribution or reproduction in other forums is permitted, provided the original author(s) and the copyright owner(s) are credited and that the original publication in this journal is cited, in accordance with accepted academic practice. No use, distribution or reproduction is permitted which does not comply with these terms. 